\title{
NORTHWEST MONTANA WILDLIFE MITIGATION HABITAT PROTECTION: ADVANCE DESIGN APPENDICES G, H, I, J
}

\section{FINAL REPORT}

\author{
Prepared by: \\ Marilyn A. Wood, Project Biologist \\ Tim Manley, R esearch Assistant \\ Montana Department of Fish, Wildlife and Parks
}

Prepared for:

U.S. Department of Energy

Bonneville Power Administration

Division of Fishand Wildlife

P-0. Box 3621

Portland, OR 97283-3621

Project Number 87-060

Contract Number DE-AI79-87BP36 137

OCTOBER 1993 


\section{TABLE OF CONTENTS}

Appendix G The Status of Columbia Sharp-tailed Grouse on the Tobacco Plains, Eureka, Montana

Appendix $\mathrm{H}$

The Financial Analysis of the Bear Creek Canyon Proposed Scenic

Easement by the Department of State Lands

Appendix I

The Department of State Lands Scenic Easement on the Soup Creek Ranch

Appendix $\mathrm{J}$

The Rocky-Bar-O Ranch Conservation Easement 


\section{APPENDIX G}

The Status of Columbia Sharp-tailed Grouse on the Tobacco Plains, Eureka, Montana 


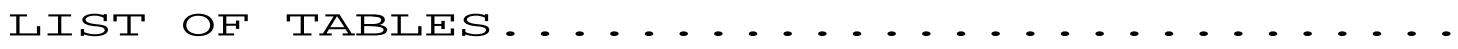

LIST OF FIGURES. . . . . . . . . . . . . . . . . . . . . . . .

ACKNOWLEDGEMENTS . . . . . . . . . . . . . . . . . . . . . . . . . V v

INTRODUCTION . . . . . . . . . . . . . . . . . . . . . . . 1

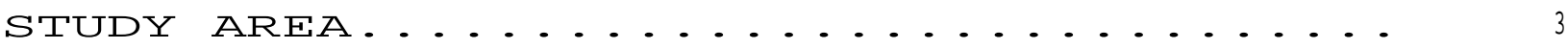

METHODS .............................. 5

Habitat Changes ................... 5

Available Habitat Priorities . . . . . . . . . . . . . 5

Habitat Comparisons. . . . . . . . . . . . . . . 6

Current Habitat Use. . . . . . . . . . . . . . . . . 6

RESULTS . . . . . . . . . . . . . . . . . . . . . . . . . 8

Historic and Current Grouse Observations . . . . . . . . . 8

Habitat Use. . . . . . . . . . . . . . . . . . 8

Augmentation Efforts ................. 13

Available Habitat Priorities . . . . . . . . . . . . 15

Comparison to Other Areas. . . . . . . . . . . . . . 15

DISCUSSION AND RECOMMENDATIONS . . . . . . . . . . . . . . . . . 19

LITERATURE CITED . . . . . . . . . . . . . . . . . . . . . . . . . . . 25 


\section{LIST OF TABLES}

Table

1. The total number of Columbian sharp-tailed grouse known to be on the active lek, April 1989. • . . . • . • • . . • . • • . .

2. Changes in habitat and land use (hectares) in the Tobacco Valley for the years 1947, 1966, and 1987. . . . . . . . . . . . . . 


\section{LIST OF FIGURES}

Figure

Page

1. The Tobacco Valley, Eureka, Montana. . . . . . . . . . . . .

2. The location of the three confirmed dancing grounds in the Tobacco

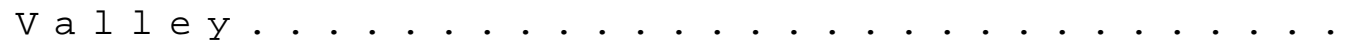

3. The total count of Columbian sharp-tailed grouse using lek \#1 (19691988 ) . . . . . . . . . . . . . . . . . . .

4. The total count of Columbian sharp-tailed grouse using lek \#2 (19761983 ) . . . . . . . . . . . . . . . . . .

5. The highest total count of Columbian sharp-tailed grouse on one day, for each year (1960-1987). . . . . . . . . . . . . . . . .

6. The top eight ranked sections for spring, summer, and fall habitat. . . . . . . . . . . . . . . . . . . . .

7. The top eight ranked sections for winter habitat . . . . . . . .

8. Soil-moisture index for the Tobacco Valley (1962-1988) . . . . 


\section{ACKNOWLEDGEMENT}

I would like to thank, among others, the following for there assistance in this study: Tom Puchlrez and the Murphy Lake Ranger Station for providing me working room, maps, and aerial photos. I would also like to thank Christie Ferruzzi for volunteering her assistance in searching for the "elusive grouse" and the Lewis Young and Guenter Heinz, two biologists that donated personal time in order to help count and shoot video of birds in the early morning hours. I would also like to express my appreciation for the help and information that Bernie Hall, Dave Genter and Rick Kerr provided. My thanks to landowners Leland Driggs, Al Luciano, Butch Cate, George Shea, and Doc Smiley for allowing me access to their properties and for providing valuable information on land use and grouse observations. My thanks to Canadian biologists Doug Jury, Anna Wolterson, and Penny Ohanjanian for their input and assistance. Finally, I would like to thank my wife, Debbi. who put up with me getting up at 3:30 in the morning to go and look for grouse. 


\section{INTRODUCTION}

Columbian sharp-tailed grouse (Tympanuchus phasianellus columbianus) have undergone declines in population and occupied range throughout much of the Intermountain West (Miller and Graul 1980, Johnsgard 1983). Former range included both the fescue-wheatgrass (Festuca-Agrophyron) and sagebrush-grass (Artemisia-Aqropyron) semidesert scrub associations (Kessler and Bosch 1981). Conversion of grasslands to agriculture and livestock grazing were the primary causes for population declines (Hart et al. 1950, Yocom 1952, Buss and Bziedzic 1955).

Historically, the Columbian sharp-tailed grouse occupied the Montana grasslands west of the Continental Divide (Siloway 1901). Saunders (1921:58) stated that is was "A fairly common permanent resident of the mountain valley. . formerly very common, but becoming rarer each year." In 1969, Columbian sharp-tailed grouse were confined to small areas in Lake, Powell, and Lincoln counties (Hand 1969). Brown (1971:129), found that fragmentary populations persisted only where major stands of bunch grasses and shrubs of the native prairie remained, and that the Columbian sharp-tailed grouse represented an endangered species in northwestern Montana.

Information and records of Columbian sharp-tailed grouse for the Tobacco Plains were sparse. Prior to 1960. the only recorded observations of sharp-tailed grouse were during the late fall and winter on a ranch at Fortine, $20 \mathrm{~km}$ south of the Tobacco Plains. One to 16 birds were observed during several different winters between 1921 and 1932 (W. Weydemeyer, pers. commun.).

The first recorded count of birds was on an unrecorded lek in 1960. In 1966, the Montana Fish and Game made its first count of ten grouse on an unrecorded lek. The Fish and Game made almost yearly counts on the leks in sections 11 and 26, from 1966 through 1974.

University of Montana professor Chuck Jonkel became interested in the grouse in 1976. Jonkel and several students collected information from 1976 through 1980. One of the students completed her senior thesis on sharptails in the Tobacco Plains (R.R. Bown, The Status of the Columbian Sharp-tailed Grouse in the Tobacco Plains, University of Montana, Missoula, 1980). Bown's report was the most complete work ever done on Columbian sharp-tailed grouse in Montana.

Since 1979, U.S. Forest Service (USFS) and the Montana Department of Fish, Wildlife and Parks (MDPWP) biologists began making almost yearly counts on the two active leks, and recorded several other sightings during the fall and winter months (L. Young, U.S. Forest Service, pers. commun.).

Since 1985 to the present, the Montana Natural Heritage Program (MNHP) and The Nature Conservancy (TNC) have been involved in conservation efforts through the establishment of the Dancing Prairie Preserve (J. Bird, P. Lesica, and B. Hall, unpubl. rep., The Nat. Conserv., Big Sky Field Office, Helena, 1987) and augmentation efforts (The Sat. Conserv., A plan for the augmentation of an existing population of Columbian sharp-tailed grouse in the Tobacco Valley, Montana, Big Sky Field Office, Helena, 1988). 
In 1984, the Montana Department of Fish, Wildlife and Parks determined that the construction of Libby Dam resulted in the loss of grassland and riparian habitat capable of supporting sharp-tailed grouse. Mitigation plans call for protection of 2,462 acres of habitat on the Tobacco Plains for Columbian sharptails. Prior to implementing the protection strategies of fee title acquisitions or conservation easements, it was necessary to determine the feasibility of maintaining a grouse population on the Tobacco Plains.

This research project was initiated in January 1989. Field work was completed by late summer. The purpose of this project was to identify reasons for the decline of the grouse population and determine the feasibility of maintaining grouse on the Tobacco Plains. Specific objectives of the project were:

1. To determine the existing and historic availability of sharp-tailed grouse habitat.

2. To document current and past grouse populations.

3. To determine the success or failure of past augmentation efforts.

4. To develop a list of potential sites to be included in a protection plan. 


\section{STUDY AREA}

The $127 \mathrm{sq} . \mathrm{km}$ study area was located in the northwestern portion of Montana near Eureka (Figure 1). The dominant topographic feature was the Rocky Mountain Trench which extended for more than $1,600 \mathrm{~km}$ in a northwest direction from Montana to the Yukon Territory. The Tobacco Plains occupied the Rocky Montain Trench between the British Columbia border and Eureka. The plans were bordered to the east by the Galton Range, to the south by the Salish Mountains, and to the west by the Purcell Mountains. Elevations ranged from $698 \mathrm{~m}$ to $820 \mathrm{~m}$. The flat surface of the plains were interrupted by glacially formed drumlin hills and kettle lakes. The principal stream through the plan was Phillips Creek, which originated in Canada.

Five community types were recognized on the proposed Dancing Prairie Preserve (P. Lesica, unpubl. rep., The Nat. Conservancy, Helena, 1986) and were representative of plant communities through the area. Native grasslands were dominated by rough fescue (Festuca scabrella) and needle and thread grass (Stipa comata). Other native grasses included bluebunch wheatgrass Agropyron spicatum Idaho fescue (Festuca idahoensis), and Sandberg bluegrass (poa sandbernii). The rare perennial forb, Spalding's catchfly (Silene spaldingii), is found within the Tobacco Plains and may be the largest population known ( $P$. Lesica, unpubl. rep., The Nat. Conserv., Helena, 1986). Shrubs along the riparian zones and in the foothills were primarily rose (Rosa spp.), snowberry Symphoricarpos spp.), black hawthorn (Crataeaus dounlasii), serviceberry (Amelanchier alnifolia) and chokecherry (Prunus virniniana). Deciduous trees included aspen (Populus tremuloides), black cottonwood (Populus trichocarpa) and paper birch (Betula papyrifera). Stands of coniferous trees were ponderosa pine (Pinus ponderosa) and Douglas-fir (Pseudotsuga menziesii).

Annual precipitation averaged $35.4 \mathrm{~cm}$ from 1961 through 1988. The majority of the precipitation occurred in the form of rainfall averaging $3.7 \mathrm{~cm}$ during May and $5.3 \mathrm{~cm}$ during June. Snow depth rarely exceeded $30 \mathrm{~cm}$, except when blown into drifts.

Mean annual temperature was 7.1 degrees C (1961-1988). Lowest average monthly temperatures occurred in January (-10.4 degrees C) and the highest average monthly temperatures occurred in July (29.3 degrees C).

Eighty-seven percent of the study area was in private ownership. Nine percent was owned by the State of Montana and four percent was under federal or county ownership. 


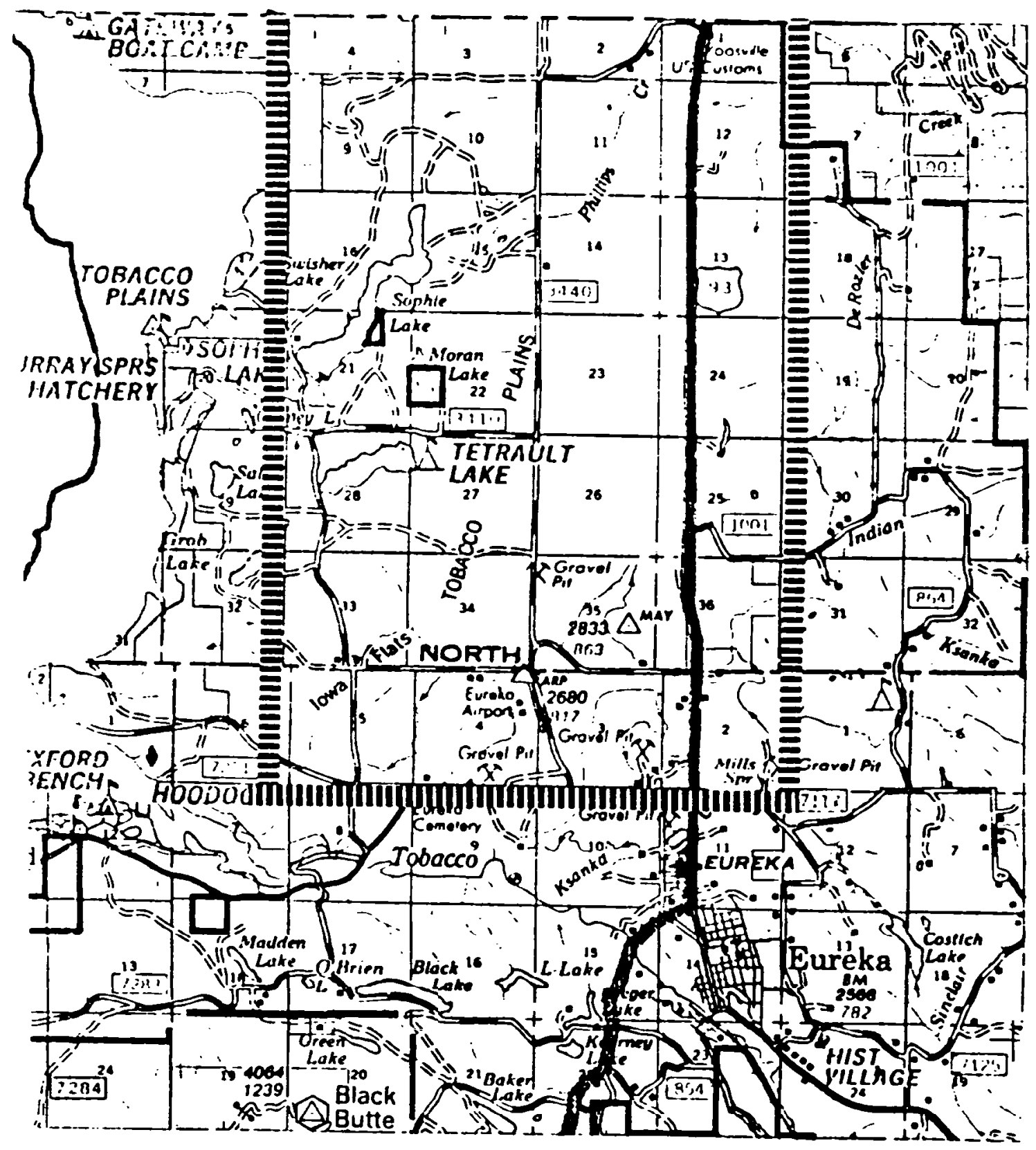

Figure 1. The Tobacco Valley, Eureka, Montana. 


\section{METHODS}

Existing and historic availability of sharp-tailed grouse habitat in the Tobacco Valley was determined through extensive literature review of seasonal sharptail habitat, review of the observation records from State, Federal, and private sources, interviews from long-time landowners, field searches, and visual observations.

An observation list was developed from historical and recent records. Information recorded included date, season, lek, number of birds, number of males, observer, location of report, and comments. Leks were numbered and lek counts were tallied by year. If the location of the lek could not be determined from the report, it was placed in the unknown category.

Assistance and cooperation was provided to The Nature Conservancy in the augmentation of Columbian sharp-tailed grouse on the Tobacco Plans. Columbian sharp-tailed grouse were trapped near Kamloops, B.C. by Canadian biologists and The Nature Conservancy. The birds were flown to Eureka, banded, placed in the release boxes, and released in the evening when the male grouse came onto the dancing ground. The dancing ground was monitored extensively for two weeks following the releases.

Habitat Changes

Changes in habitat over time were obtained by mapping vegetation and land use patterns on black and white aerial photos for 1947 and 1966, and color aerial photos for 1987. Noticeable changes in habitat were mapped and area measurements were obtained using a digitizer. For ease of data manipulation, area measurements were recorded by sections and then entered into the computer spreadsheet.

Available Habitat Priorities

In order to prioritize and direct any future efforts, a rating system was developed to compare and rank each section relative to other sections within the study area based upon the following criteria:

Spring, Summer, Fall Habitat and Use -

1. Quantity: the proportion of grassland habitat within the section.

2. Quality: the grassland areas were subjectively rated on quality based on two criteria:

(1) Residual grasses: both native and non-native grassland were rated as either excellent, good, fair-good, fair, or poor, based on the amount of residual grasses left from previous growing season. The residual grasses would provide grouse cover adjacent to the dancing grounds and would provide early nesting cover.

(2) Presence of bunchgrasses: bunchgrass ratings were abundant, moderate-abundant, moderate, occasional-moderate, occasional, and 
none. This gave an indication of the present and potential of an area to support birds based on the native bunchgrasses still present. This rating was primarily for prioritizing potential areas for future management.

3. Grouse use: historical and present sightings were classified as either confirmed, reported, or unknown. Historical use was prior to 1988, present use was 1988 and 1989.

Winter Habitat Use:

1. Quantity: the combined proportions of shrub and forested deciduous habitat within the section.

2. Grouse Use: Historical and present use.

Total Habitat and Use Rating:

1. The sum of the spring, summer, fall rating and winter ratings.

Habitat Comparisons

To help determine the suitability of the Tobacco Plains to support grouse, a quantitative comparison of habitat which still supported a good population of grouse in similar habitats was conducted. The area selected was south of Kamloops, British Columbia. Aerial photos were obtained which covered at least three known active leks. The habitat mapping covered 4,992 hectares and was conducted identical to mapping that was done for the Tobacco Plains. A general comparison of the 4,992 hectares was made to 4,996 hectares surrounding the 3 known lek sites on the Tobacco Plains. Additional comparisons of the average habitat within a $1.6 \mathrm{~km}$ radius of each of the three leks at Kamloops and the three leks on the Tobacco Plains were also made.

Information on grouse and habitat was also collected from the Tobacco Plains Indian Reserve, Newgate, Gold Creek, Cranbrook and Wycliffe areas in British Columbia.

Current Habitat Use

Winter habitat surveys were conducted during January, February, and the first week in March. Historical locations and suitable-looking habitat were searched by foot the day after a new snowfall. Grouse tracks, snow roosts, droppings, and visual observations were mapped and the site was surveyed at least weekly.

Lek surveys were conducted from the second week in March through the second week in May. Transects spaced at $0.8 \mathrm{~km}$ intervals were set up and a parabolic receiver was used to listen at each location for 15 minutes. An attempt was made to listen near and to check the top of small knolls and drumlins.

Nesting surveys were not conducted due to the small number of birds present, and to avoid any change of causing nest abandonment and/or nest predation. 
Brood surveys were conducted on three consecutive days in mid June, but due to the large search area involved and the small number of birds present, it was not continued. 
RESULTS

Historic and Current Grouse Observations

There were 137 recorded observations of sharp-tailed grouse from the Eureka and Fortine areas (Appendix A). Eight-two percent of the observations were within the study area. Seventy-four percent of the reports occurred on a dancing grouse, 4 percent from unrecorded lek(s), 81 percent from lek =1, 12 percent from Lek \#2 2 percent from Lek \#3, and 1 percent from site \#2A. Of the remaining 26 percent of the reports, 31 percent were during the spring, : percent from summer, 3 percent in the fall, and 59 percent during the winter, Eighteen percent of the reports which occurred outside the study area were in the Fortine and Trego areas (15-24 km south of the study area). These were reported by Weydemeyer (pers. commun .) for the winter months during the 1920s and early 1930s. The largest flock reported was 15 birds near Trego in November 1929. Weydemeyer also reported sharp-tailed grouse on his ranch at Fortine as recently as the winter of 1971, and the fall of 1977.

The locations of three confirmed dancing grounds are presented in Figure 2. The use of lek \#l, Section 26, was well documented and was still active. Lek \#2 was also well documented and was abandoned in 1984. Lek \#3 was also documented, the last count was in 1971.

Recorded counts of birds on lek \#1 (Figure 3) and lek \#2 (Figure 4). showed a steady decline since 1976. The highest total count for lek \#l was 33 birds on April 14, 1971. Highest count for lek \#2 was 10 birds in Hay of 1976 and 1977. Lek \#3 had a recorded high count of 21 birds on April 14, 1971. The highest total count of grouse in one day was on April 14, 1971 (Figure 5). A total of 54 grouse were observed 33 at lek \#1 and 21 at lek \#3).

Habitat Use

Winter surveys were conducted from January through the first week in March. Four sharp-tailed grouse were located in a shrub row on the "69 Ranch" on January 12, 1989. The same four birds were observed in that area during February with the last sighting occurring on March 1. 1989. A photo taken by a motion sensor activated camera, revealed that at least one of the birds was not banded. By following tracks in the snow, it was evident that the birds were feeding on hawthorn berries and rosehips.

Nine sharp-tailed grouse were observed on March 3, 1989, feeding on the buds of aspen, birch, and cottonwood trees on the Quirk Ranch. At least three of these birds were red-banded from the 1988 release. Two grouse were observed on the Hark property on March 3, 1989, about $300 \mathrm{~m}$ northeast of the Quirk location. Six birds, at least 3 red-banded, were observed on March 6, 1989. on the Quirk Ranch.

The first observed activity at lek \#1 occurred on March 10, 1989. Six males were observed (5 red bands - 1988, 1 unknown). A high count of 10 males (1 yellow band - 1987, 9 red bands - 1988) were observed March 23, 1989, and April 17, 1989. No unbanded males were observed and no females were observed prior to the release. 


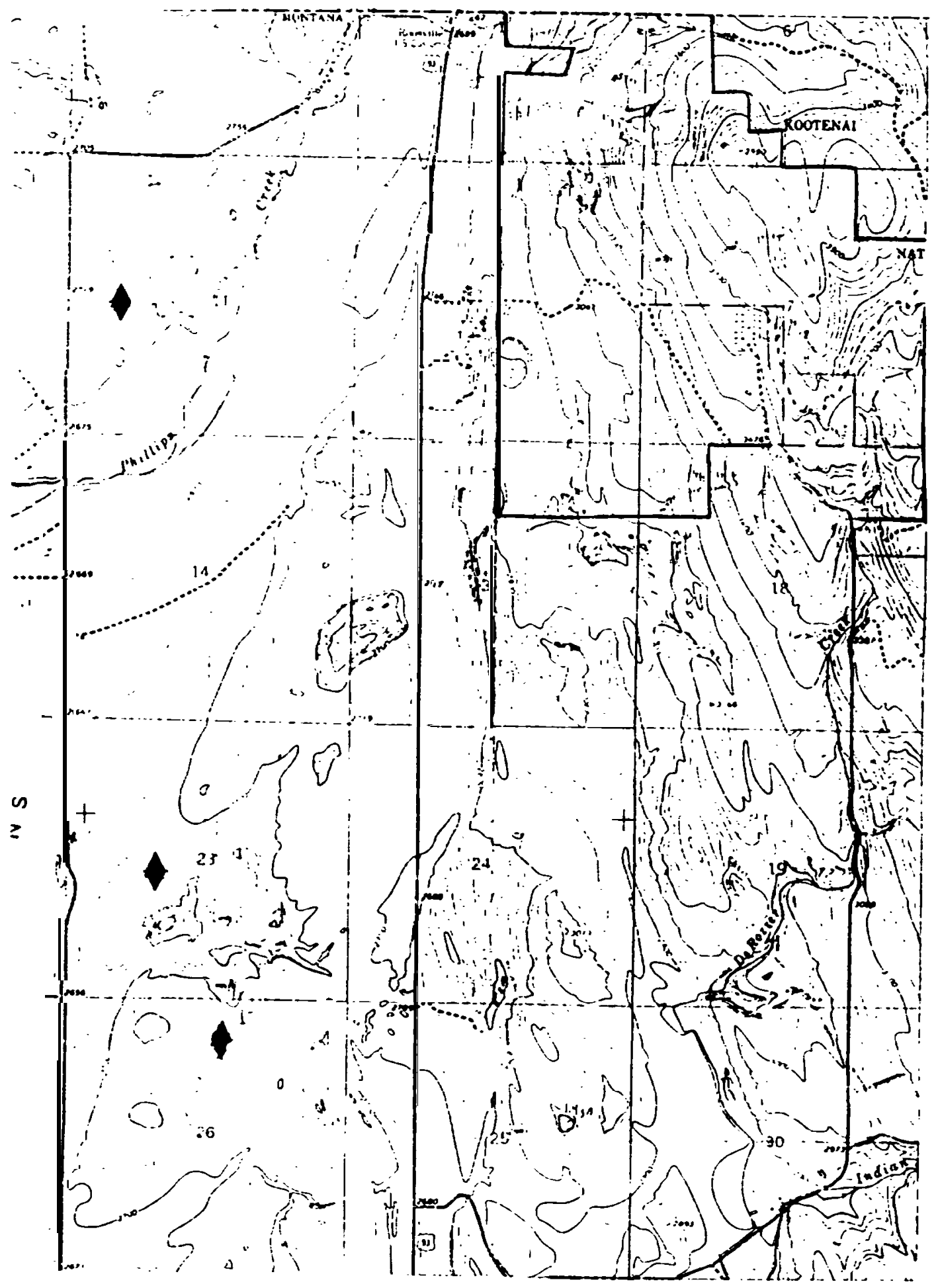

Figure 2. The location of the three confirmed dancing grounds in the Tobacco Valley. 


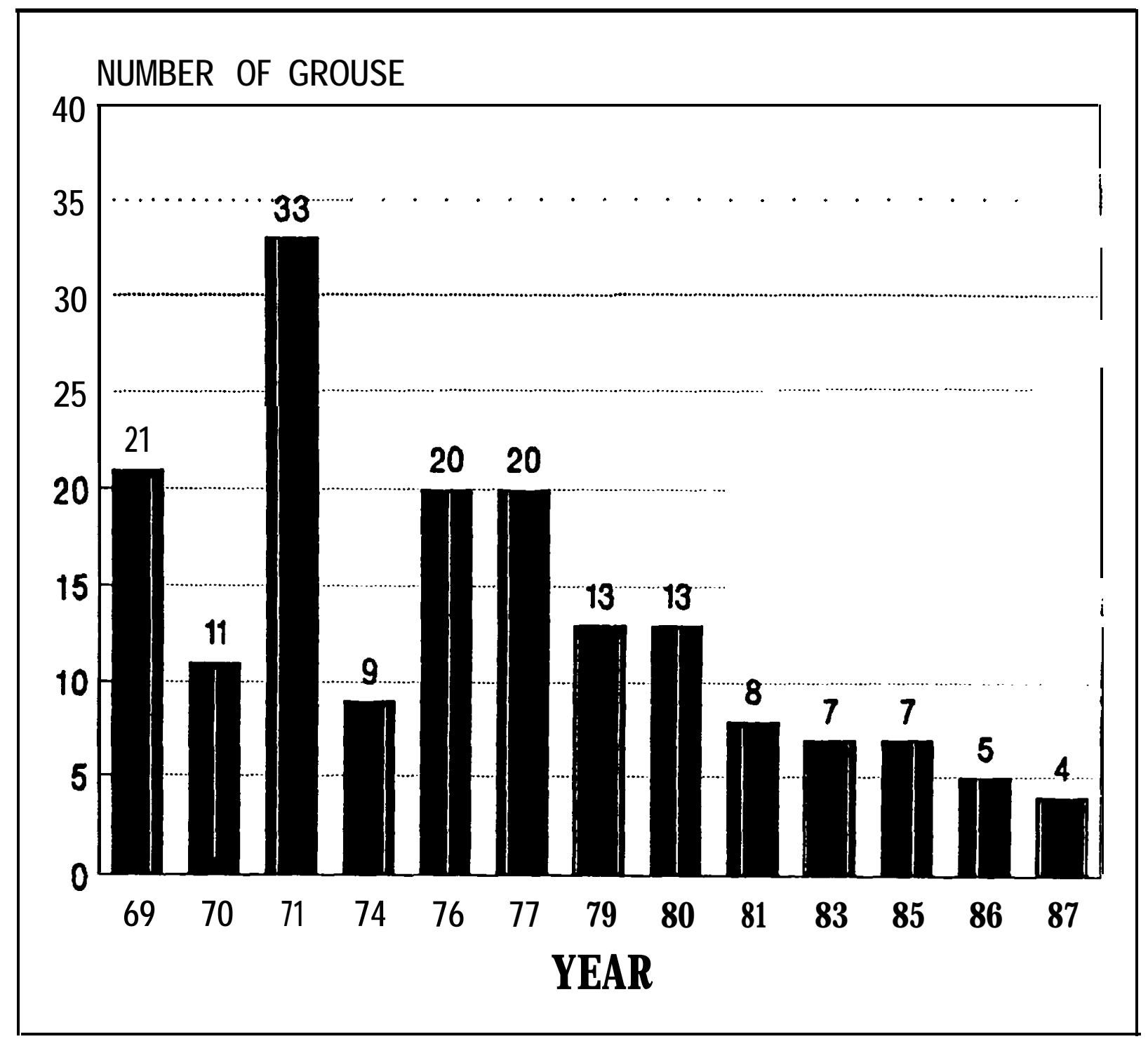

Figure 3. The total count of Columbian sharp-tailed grouse using Lek \#l (1969-1987) . 


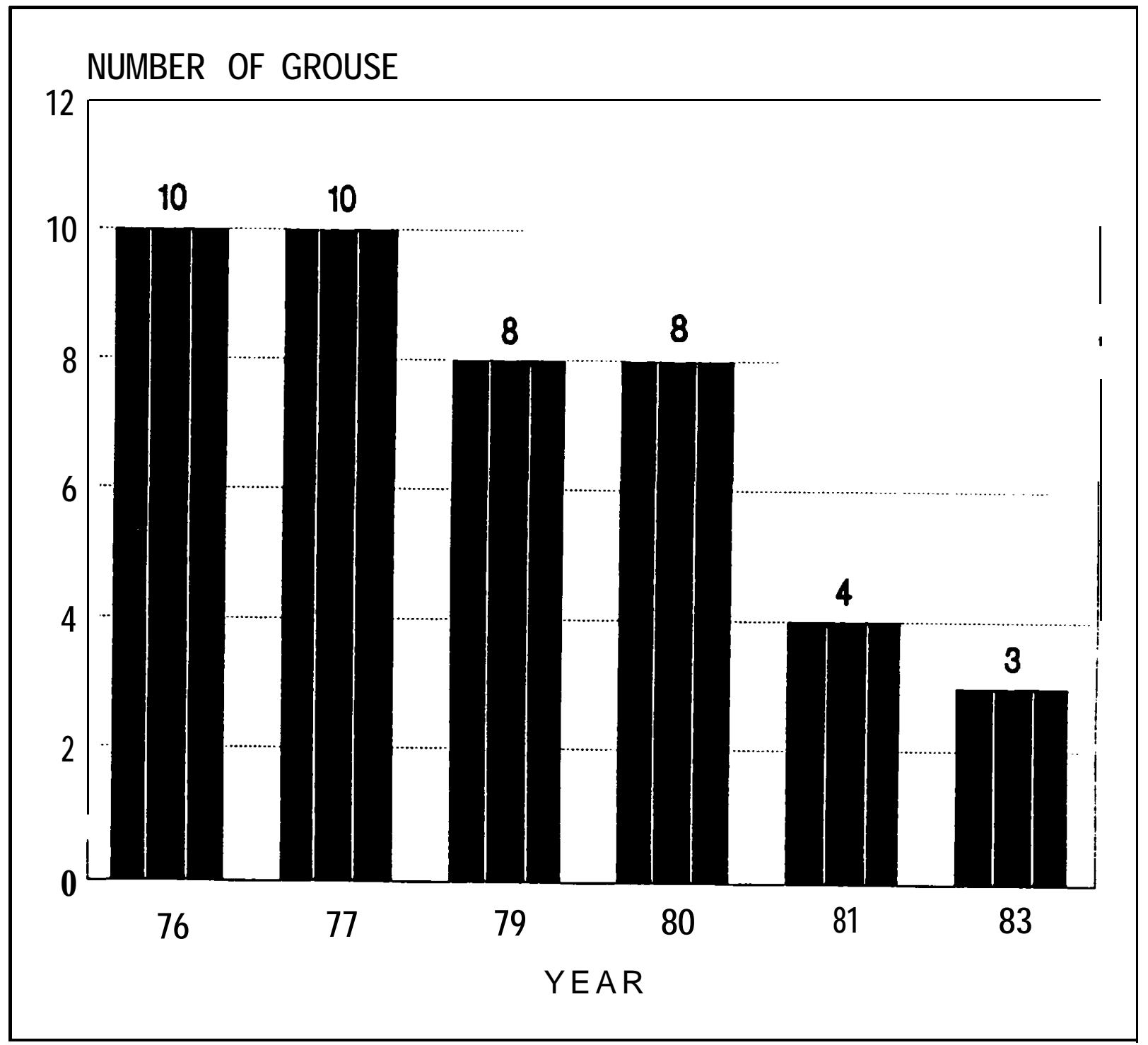

Figure 4. The total count cf Columbian sharp-tailed grouse using Lek \#2 (1976-1983). 


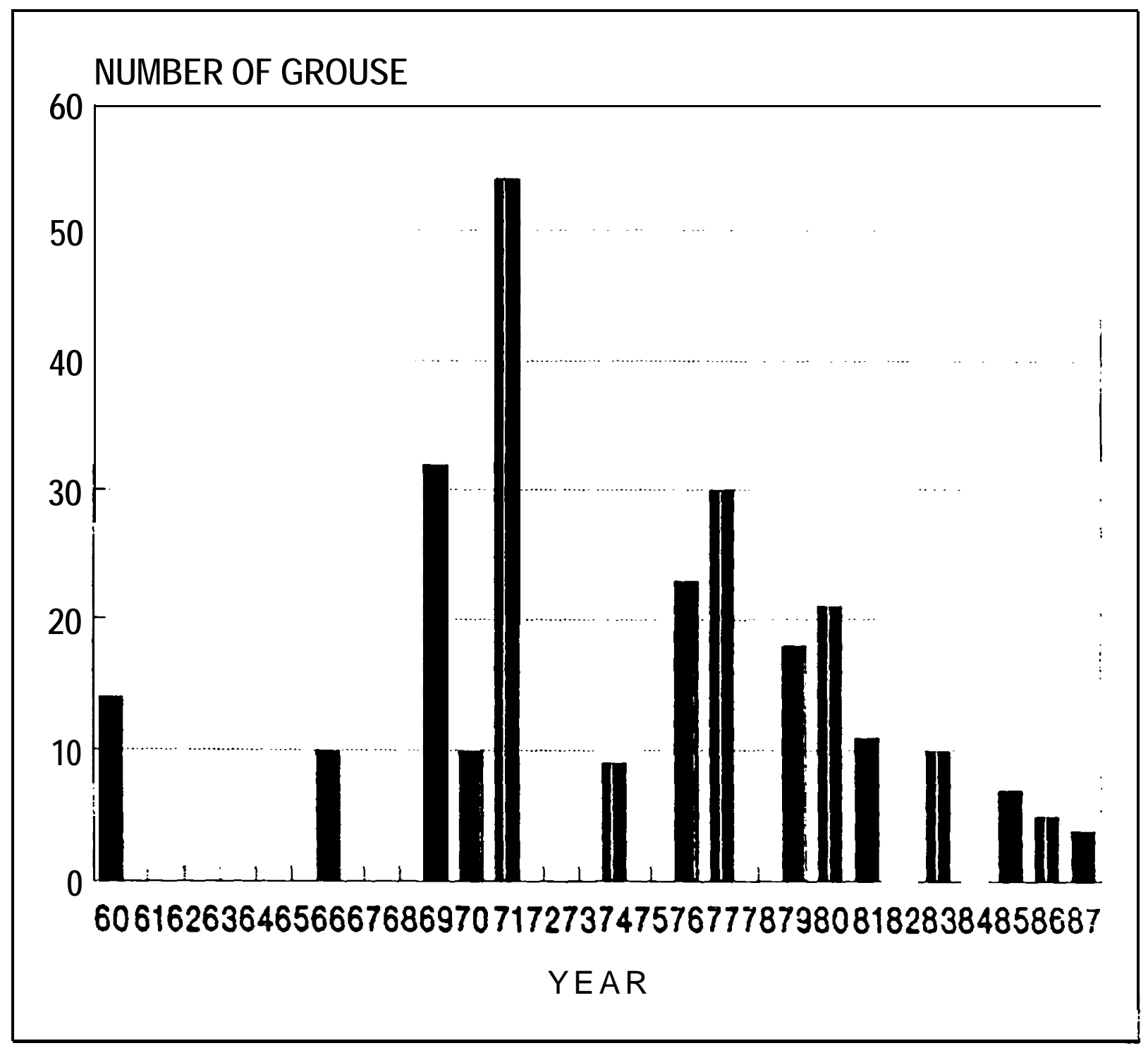

Figure 5. 'The highest total count of Columbian sharp-tailed grouse on one day, for each year (1960-1987). 
Extensive surveys to locate other leks were conducted, but none were found. There is always the possibility that a new lek, especially one with a few birds could have been missed.

Three consecutive attempts were made to locate any possible broods surrounding the dancing ground. The area was searched on foot using two persons and a zigzag route to attempt to locate birds. The effort expended was small and incomplete, and with no specific area to concentrate the effort, and with so few birds it was not continued. No birds were observed.

\section{Augmentation Efforts}

On April 17, 1989, eight females that had been captured near Kamloops, B.C., by Ministry of Environment Biologist Doug Jury. and a professor and students from Norkam Secondary, were transported by Project Lighthawk and The Nature Conservancy to the Eureka airport. The females were given blue bands on both legs, put into the release box, transported by vehicle to lek \#1 and released that evening when the males came on to the dancing ground. Upon release, the birds began feeding, preening, and immediately attracted the attention of the displaying males. The birds were allowed to disperse off the grounds before we made an attempt to leave the area. The following morning, Dave Genter, Lewis Young, and myself entered the tent blind and observed 7 males (1 yellow band 6 red bands) and 3 banded females. The females were on the dancing ground for a short period of time and one copulation was observed. Banded females were observed every morning between releases. Prior to the second release, the most birds observed were on April 20, 1989 (9 males, 4 females).

The second release of 5 birds trapped at Kamloops by Bernie Hall and Rick Kerr, occurred on April 21, 1989. A chartered plane flew the birds to Elko, B.C., where they were transferred by vehicle to the release site. The 4 males were banded with a blue and a yellow band on different legs, the female was given blue bands. The five birds were released that evening using the same technique as before. Fourteen birds (10 males, 1 yellow, 8 red, 1 yellow/blue, and 4 females, 2 blue and 2 unknown) were observed on April 27, 1989. Three copulations were observed after the second release. On April 28, 1989, an unbanded female was observed on the dancing ground. Table 1 lists the breakdown for the total number of birds known to be on the lek before, during, and after the releases.

Table 1. The total number of Columbian sharp-tailed grouse known to be on the active lek, April 1989.

Unhanded males

Yellow banded male (1987)

Red banded males (1988)

Yellow/blue males (1989)

Unbanded females

Blue banded females (1989)

0

1

9

4

1

9

Total 
On June 5, 1989, two sharp-tailed grouse were observed sitting on a fence northeast of Eureka, but the observer was unable to determine if the birds were banded before they flushed. No observations or reports of sharp-tailed grouse have been received since.

Habitat mapping of 12,534 hectares for 1947, 1966, and 1987 showed little change in actual quantity of habitat (Table 2).

Table 2. Changes in habitat and land use (hectares) in the Tobacco Valley for the years 1947, 1966, and 1987.

\begin{tabular}{lrrr} 
Grassland & 7,191 & 6,222 & 5,905 \\
Bitterbrush/burn & 50 & 224 & 224 \\
Shrub & 102 & 94 & 94 \\
Forest-deciduous & 242 & 231 & 231 \\
Forest-coniferous/shrub & 46 & 152 & 152 \\
Forest-coniferous & 2,768 & 2,700 & 2,697 \\
Agricultural & 1,460 & 2,156 & 2,370 \\
Water & 227 & 227 & 230 \\
Development & 448 & 528 & 631 \\
Total Hectares & & 12,534 & 12,534 \\
\hline
\end{tabular}

A decrease in grassland from 1947 to 1987 of about 18 percent, an increase in agricultural land of 62 percent, and an increase in development of 41 percent were the major noticeable changes. Basically, the same shrub and forested deciduous patches that were present in 1947 were still present in 1987. coniferous forests still covered the same areas as in 1947, although it was evident that some were more dense in recent years, particularly in the Sophie Lake area. The mapping of habitat over time was able to document quantitative changes, but not qualitative.

In interviews with former residents along the Kootenai River and with persons familiar with that area, it was my consensus that sharp-tailed grouse did use the deciduous forests along the river during the late fall and winter. Mapping of habitat along the Kootenai River prior to the construction of Libby Dam revealed the amount of habitat lost. In terms of potential winter habitat which would include riparian shrub, cottonwood riparian. and mixed riparian. a total of 752 hectares were lost. As far as breeding, nesting, and brood rearing habitat, there is no evidence that sharp-tailed grouse did or did not use the area along the river during that time. If birds did use the area, then there were 546 hectares of grassland habitat inundated. 


\section{Available Habitat Priorities}

Results of the rating system revealed that the top 8 rankings for the spring, summer, and fall rating formed a 20.5 square $\mathrm{km}$ area that was $3.2 \mathrm{~km}$ wide and $6.4 \mathrm{~km}$ long (Figure 6). The highest ranking section was 26 . This section contained the active lek, had historical use, and was 99 percent grassland. The second ranked section, 23, was the location of lek \#2, and contained 98 percent grassland of which 38 percent was in good condition with 55 percent in fair condition. Bunchgrasses were abundant on 94 percent of the section. The next six areas had at least 78 percent of the area in grassland, had reports of grouse use, and section 11 was the site of lek \#3.

Ranking of winter habitat which included the shrub and forested deciduous habitats showed a concentration area east of Highway 93 which was 15.6 square $\mathrm{km}$ in size (Figure 7).

Comparisons to Other Areas

General comparison mapping of 4,992 ha of sharp-tailed grouse habitat near Kamloops, B.C., and 4,996 ha of sharptail habitat in the Tobacco Plains, revealed that similar amounts of grassland habitat were found on the Tobacco Plains (69 percent) and Kamloops (67 percent). There were more agricultural lands in the Tobacco Plains (14 percent) compared to 6 percent at Kamloops. The Kamloops area was more developed (5 percent), had more coniferous forest (17 percent), and more deciduous forest (4 percent) than the Tobacco Plains (1 percent development, 12 percent coniferous forest, and 2 percent deciduous forest). There was no difference in the amount of shrub habitat (.6 percent in the Tobacco Plains and .5 percent at Kamloops).

Comparison of the average proportion of habitat within a $1.6 \mathrm{~km}$ radius of three active leks near Kamloops and the three known lek sites in the Tobacco Plains revealed that the Tobacco Plains had more grassland ( 88 percent) than did the Kamloops areas ( 84 percent). The Kamloops area had more wintering habitat closer to the lek sites (2 percent deciduous forest and .5 percent shrub) compared to the Tobacco Plains (.4 percent deciduous forest and .006 percent shrub). There was also more development (2 percent) near the Kamloops leks compared to .3 percent in the Tobacco Plains. There was no difference between the amount of coniferous forest and agricultural land $(5$ percent and 6 percent respectively).

Qualitative differences in habitat were not measured, but the highest density of birds and leks in the Kamloops area occurred on the better managed rangelands (D. Jury, pers. commun.).

The average distance between the three leks at Kamloops was $2.5 \mathrm{~km}$ compared to $2.9 \mathrm{~km}$ in the Tobacco Plains.

A study was being conducted in the Cranbrook, Wycliffe and Tobacco Plains area in southern British Columbia to determine the status of Columbia sharp-tailed grouse in those areas. Meetings with the B.C. biologists revealed that sharptailed grouse populations had declined dramatically over the years and only a few birds had been located recently. Reasons for the decline included forest 


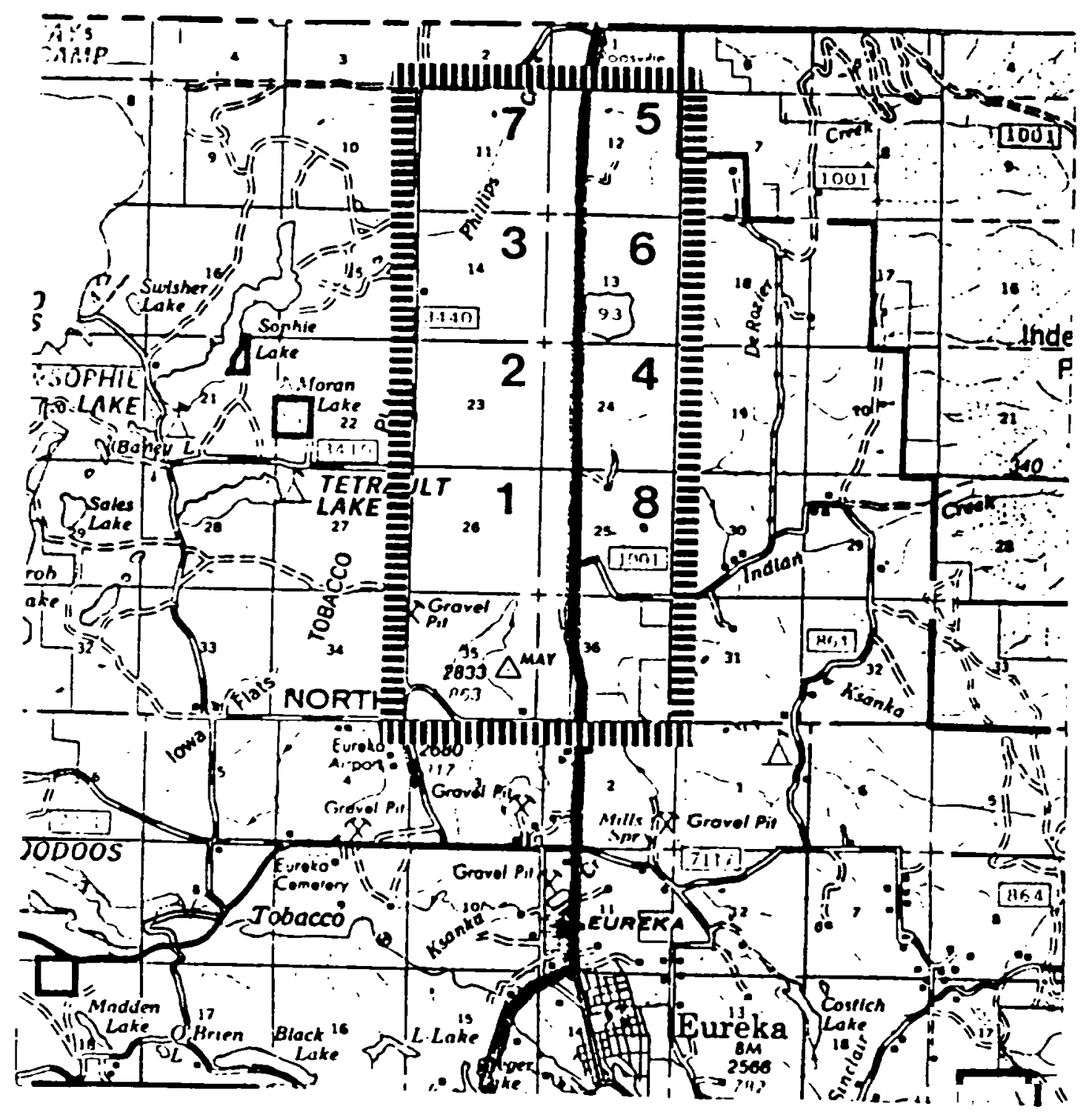

Figure 6. The top eight ranked sections for sp ring, summer, and fall habitat. 


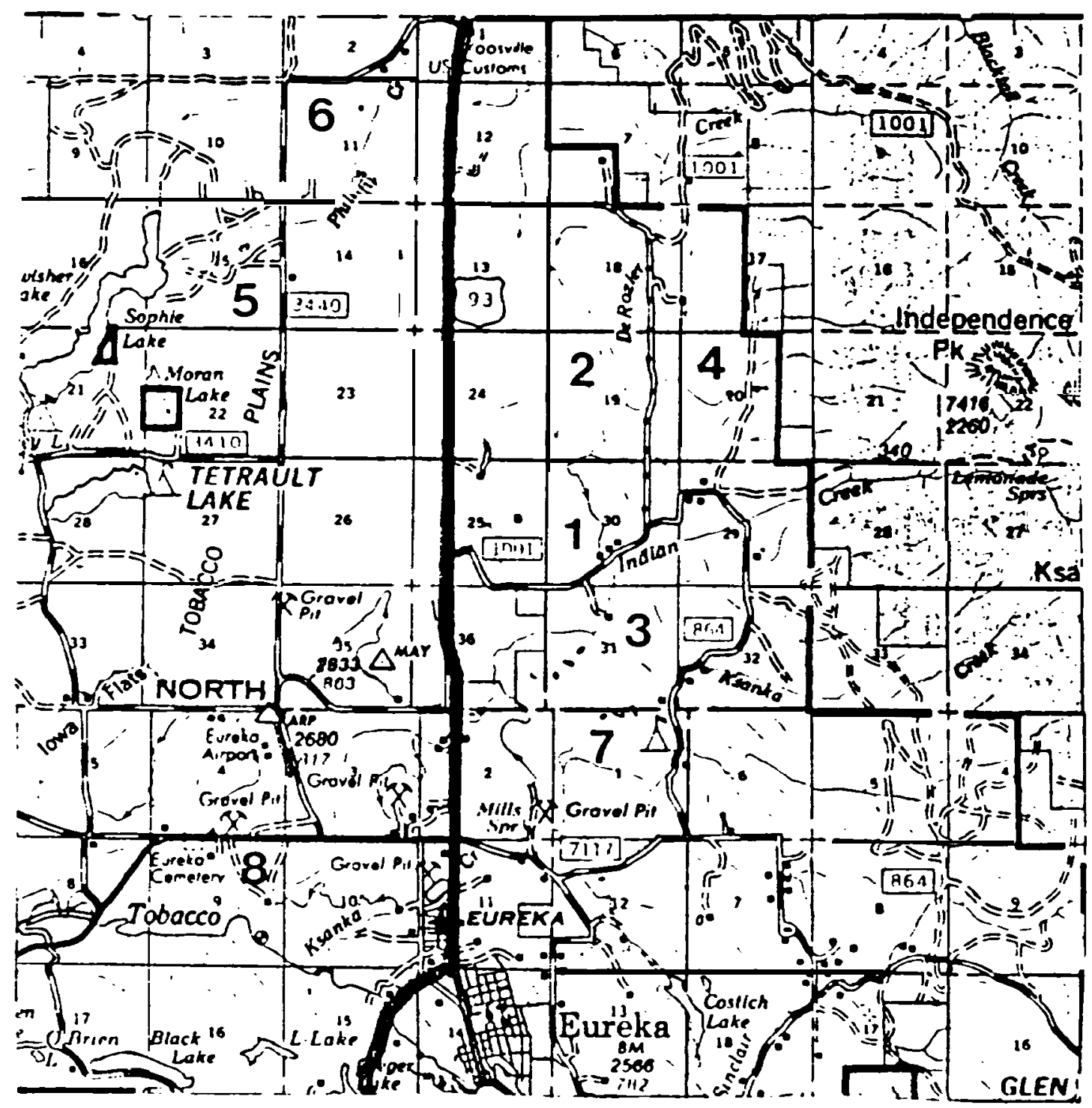

Figure 7. The top eight ranked sections for winter habitat. 
encroachment on grasslands, heavy cattle grazing, and residential development. The study is scheduled to be completed in 1990.

The Tobacco Plains Indian Reserve which was immediately north of the study area, historically supported sharp-tailed grouse but heavy cattle grazing has eliminated nesting and brood rearing cover (P. Ohanjanian, pers. commun.). British Columbia biologists felt that there was no possibility of influencing or changing the land use practices on the Indian Reserve.

The Newgate and Gold creek areas located in B.C. on the west side of Lake Koocanusa supported sharp-tailed grouse until the mid 1970s. There is a large bunchgrass/bitterbrush flat called Sharptail Pasture that sharp-tailed grouse were often observed using in the past. Loss of winter habitat along the Kootenai River may have been the biggest factor in the decline of the sharptailed grouse in this area (P. Ohanjanian, pers. comrnun.). 


\section{DISCUSSION AND RECOMMENDATIONS}

Why have Columbian sharp-tailed grouse numbers in the Tobacco Valley declined? In general, populations decline because recruitment and mortality have failed to balance. The difficult questions to answer area: What is the reason(s) for these changes and what is preventing the population from increasing?

Many researchers have attempted to explain the factors that influence recruitment and mortality and why grouse population fluctuate. Overgrazing by cattle has been identified as a limiting factor to sharp-tailed grouse populations by influencing the amount of residual cover around the dancing grounds (Brown 1968, Pepper 1972). This residual standing cover provides hiding cover for both males and females when they are off the dancing grounds. Bown (The status of the Columbian sharp-tailed grouse in the Tobacco Plains, Univ. of Montana, Missoula, 1980) found that there was a significant difference between the available cover on the active dancing grounds than on the abandoned ground. The active grounds had a higher degree of cover at all levels. Since Bown's report, lek 2 has been abandoned, and the number of grouse using lek \#1 has continued to decline. The area surrounding lek \#1 had been ungrazed or lightly grazed while Bown was studying the grouse. If loss of residual cover adjacent to the dancing grounds was a factor in the abandonment of the sites in the Tobacco Valley, was it because the hiding cover was inadequate and the adult birds were subject to increased predation? Perhaps the grouse moved to a different dancing ground. Is it possible that lek \#3, which was abandoned in 1972 became lek \#2, which was not discovered until 1976? We will never know and can only conjecture, but perhaps a third theory that the removal of the residual standing cover actually had the greatest impact on nesting should be addressed.

Aldous (1943) and Brown (1968) found that overgrazing was a limiting factor to nesting success in their study areas. Sharp-tailed grouse begin nesting in residual cover from the previous growing season and they rely on herbaceous plant cover to hide nests (Bergerud and Gratson 1988). Studies show that nesting success in sharp-tailed grouse is low (54 percent) (Bergerud and Gratson 1988). They attribute the low nest success in the steppe habitat to several reasons, including reduction of nesting cover by grazing and herbicides, and the loss of grass and sagebrush communities to agriculture, which results in concentrating nesting females and therefore reduces the size of areas that predators need to search for prey. This could certainly apply to the Tobacco Valley. The main problem of exploring this idea further is that there is no nesting information for the Tobacco Valley. The location of nesting sites are unknown. Are the grouse nesting close to the dancing ground or are they moving about the valley searching for nest sites? When and if a location is selected, are the nest successful? If unsuccessful, do the grouse renest and what percentage of those nests are successful? Are they nesting in agricultural lands? These questions need to be answered for the Tobacco Valley sharptails in order to effectively manage the population.

Soil moisture was evaluated by Bergerud and Gratson (1988) to determine if there was a correlation between breeding success in North and South Dakota and Minnesota by calculating a soil-moisture index. The theory is that the previous 23-month total precipitation from september in year 1 until July in year 3 would account for both residual and new cover. Bergerud and Gratson (1988) found that 
sharptail production was significantly correlated with the soil-moisture index in both North and South Dakota, but not in Minnesota where rainfall was greater. Bergerud and Gratson (1988) concluded that a major annual variable in sharptailed grouse production is the abundance of nesting cover as it is influenced by soil-moisture in areas of low rainfall.

A soil-moisture index for the Tobacco Valley from 1962-1988 is shown in Figure 8. The total 23-month rainfall varies from a low of $49 \mathrm{~cm}$ to a high of $92 \mathrm{~cm}$ (which is very similar to Bergerud and Bratsons (1988) range of $58 \mathrm{~cm}$ to $95 \mathrm{~cm}$ for North Dakota). It is very evident that during the 1970s, the soil-moisture was below the average of $69 \mathrm{~cm}$ during all years. This brings up additional questions. Since soil moisture has been correlated with breeding success, could the decade of low soil moisture during the 1970s have been mostly responsible for the decline of sharp-tailed grouse in the Tobacco Valley? With the limited population surveys and estimates, it is difficult to say for sure, but it could definitely have been a major factor.

Chick mortality is another factor which should be addressed. Again, there is no data for the Tobacco Valley, but some common known causes of chick mortality can be discussed in general. Bergerud and Gratson (1988) list three known causes of chick mortality: (1) chilling form weather; (2) predation; and, (3) starvation. During the first two weeks of age, chicks cannot thermoregulate, and cold wet springs can cause mortality. However, sharp-tailed grouse actually show improved chick survival in wet springs. The months of May and June are traditionally wet for the Tobacco Valley, with rainfall averaging $3.7 \mathrm{~cm}$ and 5.3 $\mathrm{cm}$ respectively.

Predation on chicks by raptors, ravens, and coyotes, may be a major factor in the Tobacco Valley. These predators are certainly present in the Valley, and in the case of ravens, an artificially high population may be a major factor on both nests and chicks during the first two weeks of age.

Starvation of chicks during the first two weeks of age when the availability of high-quality food is critical, affects chick mortality. The reduction of insect populations after chemical spraying may greatly affect chick survival. In the Tobacco Valley, the pesticide dieldrin was used in the early 1960s to reduce the grasshopper population. I was unable to track down the time period the spraying was done or the extent of the application, but it apparently covered a majority of the valley (R.R. Bown, pers. commun.). McEwen and Brown (1966) found that dieldrin was toxic to adult birds and in sublethal dose could impair the birds ability to survive and reproduce.

Nesting success and survival of chicks through the first summer all contribute to recruitment. The death of juvenile birds and adults contribute to the mortality portion of the equation.

Sharp-tailed grouse live in high-risk habitats and populations face high mortality from predation (Bergerud and Gratson 1988). Hart et al. (1950) listed 100 percent of his sharp-tailed grouse mortality was caused by predation. The literature basically states that if cover is decreased, it increases the chances of predation on nests, chicks, juveniles, and adults. If mortality is greater than recruitment, then the population will decline. Is this basically 


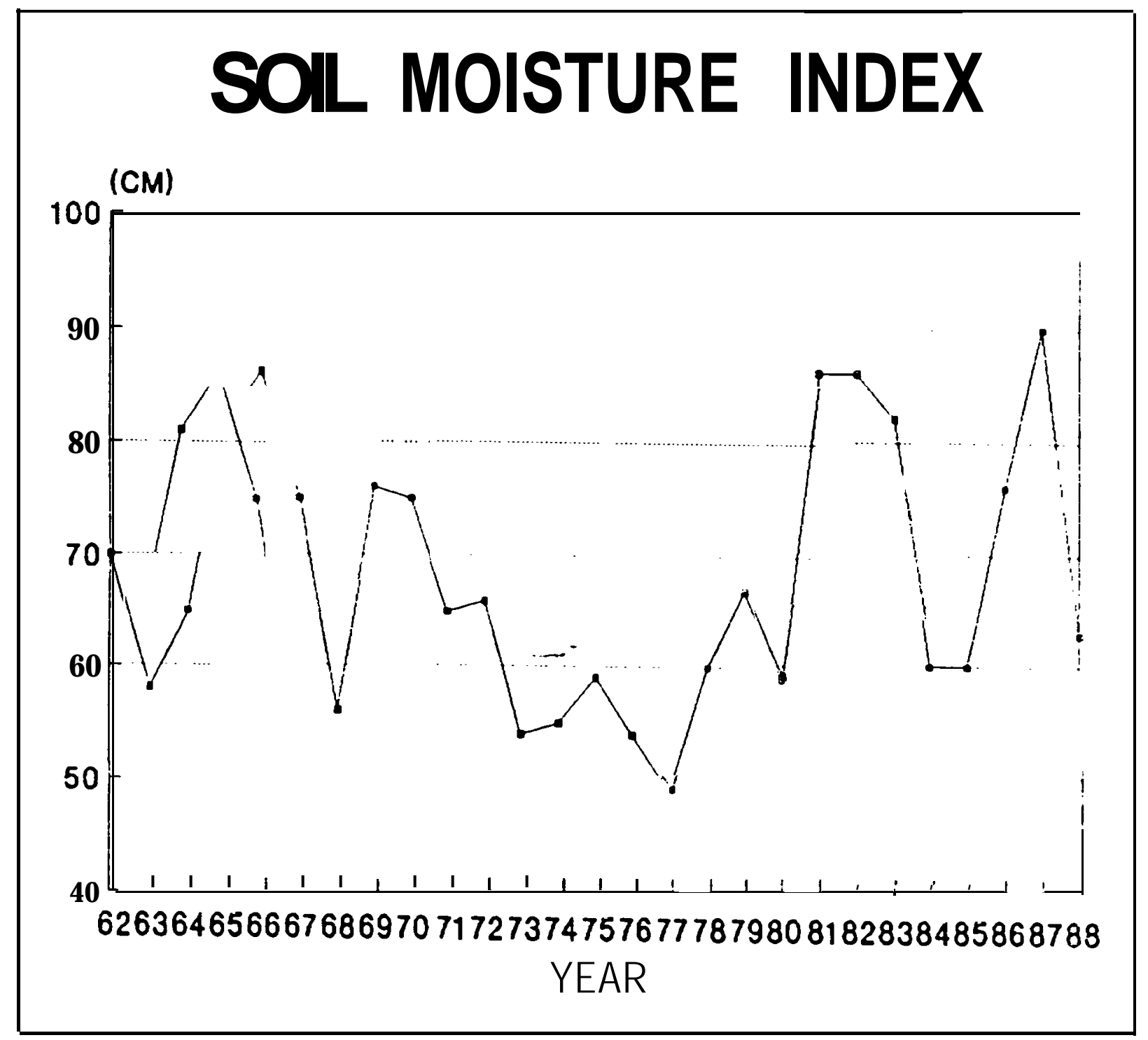


what has happened in the Tobacco Valley? Has the heavy grazing reduced nesting and brood cover? Has heavy grazing also trampled and opened up shrub and deciduous winter ranges, making juveniles and adults more susceptible to avian predation? or are density dependent factors more at play? Has the loss of wintering habitat along the Kootenai River forced the birds into more concentrated wintering sites, therefore narrowing down the area that predators need to search (the threshold of security hypothesis)? Or the winter bottleneck hypotheses, that the availability of winter foods is variable and in short supply. If the fact that only 2.6 percent of the Tobacco Valley is available as winter habitat since the creation of Lake Koocanusa caused a winter bottleneck? We have information that verifies that sharp-tailed grouse did winter along the Kootenai River, to what extent we don't know.

Again, concerning Columbian sharp-tailed grouse in the Tobacco Valley, there is a lot that we don't know. But, we may know enough in order to turn the decline around and with a concerted effort, proper management, and additional information, it may be possible to maintain a population of Columbian sharptailed grouse in the Tobacco Valley. In order to steer us in the proper direction, lets take a look at what we do know and some places to start:

1. The active dancing ground (lek \#1) is the only one we know of in the valley, and that makes it and the area surrounding it of utmost importance. Until we know if the grouse are nesting near the ground or throughout the valley, we should assume that providing nesting, brood rearing, and escape cover adjacent to the dancing ground is of primary importance. This has already been identified as a goal by The Nature Conservancy, and they should be supported in their effort. Maintaining cover does not mean that grazing should not be allowed. Proper grazing management may actually benefit sharptail habitat by removing some of the downed matted vegetation that has accumulated in ungrazed areas.

2. Cover management throughout the valley is important. Management must be directed at improving the concealment of nests and hens. Nesting hens usually need dense cover, whereas chicks usually need some openness in which to hunt insects. The bunchgrasses may offer both the cover to hide eggs and hens, and also the open spaces for chicks. By nesting in bunchgrasses, hens may also have the visibility to detect predators. Management should, therefore, be aimed toward managing for bunchgrasses.

At the present time, the important areas are the "69" Ranch surrounding the dancing ground. The areas of bunchgrass in section 23, the principal landowner being Al Luciano, and portions of the Quirk Ranch. Landowner agreements and active participation would be the desired course of action. These landowners have shown an interest in the sharptail grouse, and by talking with them and developing a sound management strategy with them they may be willing to participate.

3. During the winter, the sharp-tailed grouse move into the shrubs and small stingers of deciduous forests to feed and for cover. Providing secure feeding sites that allow the birds escape from raptors and ground predators is important. It must be remembered that sharptails also use snow burrows as a form of winter cover and that providing the correct 
juxtaposition of shrubs and large open areas where snow can accumulate is important.

Areas that we know are important include the shrub row and adjacent drumlin on the "69" Ranch, the shrub and deciduous forests on the Quirk Ranch along the Burma Road, also the shrub and deciduous forest on the Hark property, and perhaps the deciduous forest along Indian creek on the "69" Ranch. These are all areas that the grouse used last winter. They would not need any habitat improvement at this time, but protection of these sites should be of prime importance.

Areas that could be important for winter habitat include the Phillips Creek area. This deciduous forest and shrub area is in immediate need of protection and habitat improvement. Cattle have beat down most of the shrubs and there is no chance for regeneration of the aspen. Fencing and planting would greatly improve this area in the future as sharptail winter habitat. the primary landowner is Al Luciano, and again, by working cooperatively with him, some sort of protection and improvement project may be possible.

4. The transplant efforts have been very successful and should be continued while the habitat work is commencing. I think the techniques used to release the birds have proven effective. It has been demonstrated that the males will return to the dancing ground and display, and that females will actually visit the dancing ground the day after they are released and breed. The unknown at the present time is if they can successfully nest and if there will be any recruitment in the future.

5. Additional information needs to be gathered. In order to determine where the important nesting, brood rearing, and winter areas are, we need to be able to radio track some of the females and males. We need to know what these birds are doing, the habitat they are selecting, are they successfully nesting? Unless we are able to follow the birds, we will not know. I was able to locate birds during the winter, but it was very time consuming and there was no chance of finding them when you needed to, such as during the nesting and brood rearing season.

6. Cooperation and open communication between all parties involved will be utmost importance. The Department of Fish, Wildlife and Parks needs to clearly define its goals and objectives for sharp-tailed grouse in the Tobacco Valley as does The Nature Conservancy. Agreement on key areas and strategies must be planned out. Landowners have to be contacted and informed of any plans and they need to be brought into the process as does the local community groups. There appears to be a lot of public interest in the sharp-tailed grouse in that area and the general public needs to be informed on a regular basis as to what is going on.

The Tobacco Valley may be one of Montana's few places in which Columbian sharp-tailed grouse can still inhabit. By being an "island" it may give the greatest change for successful transplants and by proper managemen in key location, maintaining a viable population may be possible. The original Columbian sharp-tailed grouse were able to hang on into the mid 
1980s without help, but without the transplants the last three years, we would have lost them. With inaction we will lose them, and once we do, no one knows if it would be possible to re-establish them. 
Aldous, S.E. 1943. Sharp-tailed grouse in the sand dune country of northcentral North Dakota. J. Wildl. Manage. 7:23-31.

Bergerud, A.T., and M.W. Gratson, editors. 1988. Adaptive strategies and population ecology of northern grouse. Vol. 2. Univ. of Minnesota Press, Minneapolis, Minn. 760 pp.

Brown, R.L. 1968. Effects of land-use practices on sharptail grouse. Mont. Fish and Game Dept. Proj. W-91-R-9, Job II-F. 11 pp. Mimeo.

- 1971. Sharp-tailed grouse. Pages 129-133 In T.W. Mussehl and F.W. Howell, ed. Game management in Montana. Montana Fish and Game Div. Helena, Montana. 238 pp.

Buss, I.O., and E.S. Dziedzic. 1955. Relation of cultivation to the disappearance of the Columbian sharp-tailed -grouse from southeastern Washington. Condor 57:185-187.

Hand, R.L. 1969. A distributional checklist of the birds of western Montana. Univ. of Montana, Missoula. 51 PP-

Hart, C.M., O.S. Lee, and J.B. Low. 1950. The sharp-tailed grouse in Utah, its life history, status, and management. Utah Dept. Fish and Game publ. 3. $80 \mathrm{PP}$.

Johnsgard, P.A. 1983. Grouse of the world. Univ. Nebraska Press, Lincoln. $413 \mathrm{pp}$.

Kessler, W.B. and R.P. Bosch. 1981. Sharp-tailed grouse in range management practices in western rangelands. In Proc. Wildlife/Livestock Syrup. Coeur d' Alene, Idaho.

McEwen, L.C., and R.L. Brown. 1966. Acute toxicity of dieldrin and malathion to wild sharp-tailed grouse. J. Wildl. Manage. 30:604-611.

Miller, G.C. and W.D. Graul. 1980. Status of sharp-tailed grouse in North America. Pages 18-28 In Proc. Prairie Grouse Symp. Stillwater, Oklahoma.

Pepper, G.W. 1972. The ecology of sharp-tailed grouse during spring and summer in the aspen parklands of Saskatchewan. Saskatchewan Dept. of Nat. Res. Wildl. Rep. No. 1. 55 PP.

Saunders, A.A. 1921. A distributional list of the birds of Montana. Pac. Coast Avidfauna No. 14, Cooper Ornithological sot.

Siloway, P.M. 1901. Summer birds of Flathead Lake. Bull. of the Univ. of Montana. Bull. \#l, Biol. Series \#l.

Yocom, C.F. 1952. Columbian sharp-tailed grouse in the state of Washington. Amer. Hidl. Natur. 48:185-192. 
Observation of sharp-tailed grouse in the vinicity of the Tobacco Plains, Montana. 


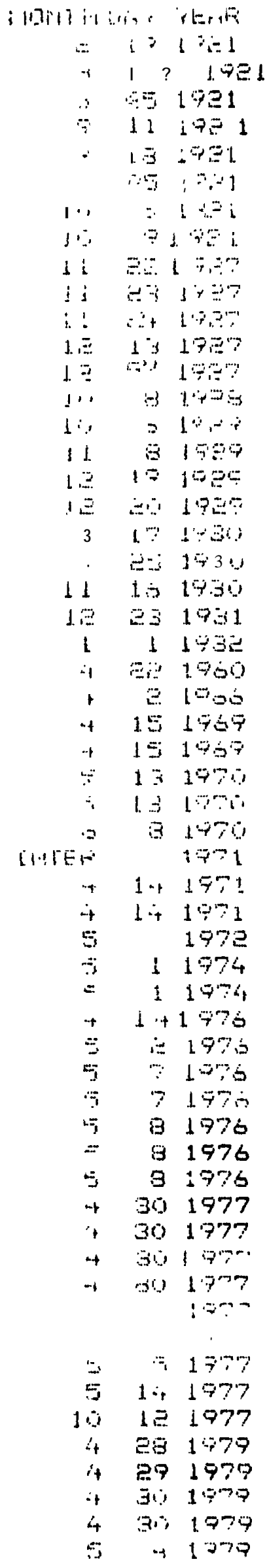

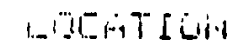

FRT I I EE FIMUNH

FOF I I NEE RIMULH

FIFTIIIF FHIEH

FDFT I I IF BIAUH

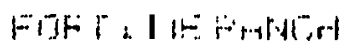

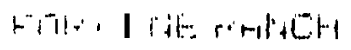

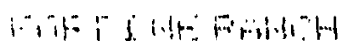

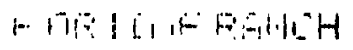

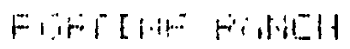

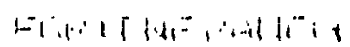

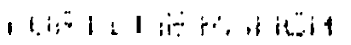

…

-

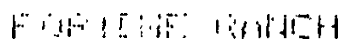

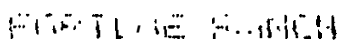

riteso

For T I ME FHAH

FOFT INE FITHCH

F GF I IME FERWLH

FUA

FIFT IIUE RARLCH

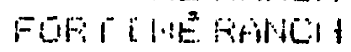

FUF: IIHE FAHULH

LAH - GROUNO

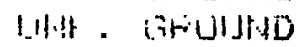

$$
\text { : } 11
$$

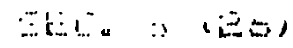

Iithation

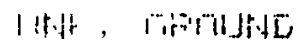

G. Miditu (2b)

Fit i is:E FinH

it. Grand (11)

5. Gium (20) Ba.T30,FE?

NEFFE FOTOO N A GROUNO

S. Ground (as)

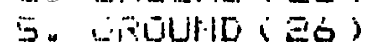

$$
\text { SEC }=\dot{0}
$$

GE $1,4,35, T 36.527$

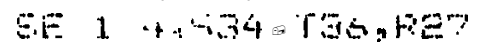

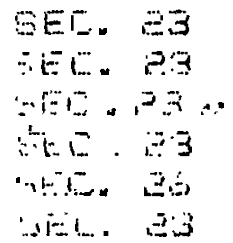

G4 1 1. BEs, T 3? , FE7

. $111^{\circ} .0 \mathrm{~s}$

, . 3

\begin{tabular}{|c|c|}
\hline $\begin{array}{l}\text { iEt: } \\
9 \%\end{array}$ & 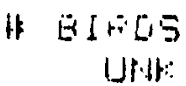 \\
\hline$\overline{7} \cdot \overline{7}$ & UNH: \\
\hline$\because \gamma$ & Litsk. \\
\hline 77 & IItip: \\
\hline $4+$ & whth: \\
\hline $9 \%$ & iritt \\
\hline 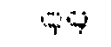 & iii it \\
\hline تَ'4) & 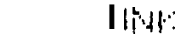 \\
\hline 97 & 1 \\
\hline $8 \mathrm{r}$ & 1 \\
\hline$\because 7$ & 1 \\
\hline$\nabla=7$ & 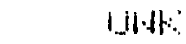 \\
\hline$\Rightarrow$ & ur $\sharp t:$ \\
\hline 7.7 & Whit \\
\hline$\because \cdots$ & 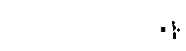 \\
\hline 9 & 13 \\
\hline 49 & 4 \\
\hline $7 \%$ & ك. \\
\hline$=\%$ & 1 \\
\hline$\because 7$ & 4 \\
\hline 97 & UIr.te: \\
\hline 99 & $\Xi$ \\
\hline 57 & UtAt \\
\hline 11 & 14 \\
\hline 0 & 10 \\
\hline-1 & 11 \\
\hline$\because t$ & こُ \\
\hline $7 \overline{7}$ & 1 \\
\hline 8 & 7 \\
\hline
\end{tabular}

$\therefore \therefore \approx$

FUFT IIUEFREH

नEE, 20

irr. 0

$\because \therefore, \ldots$

$\because 1.0$

$\therefore 1+20$
11

04 Uth

(3)

(1)

79

97

$\because 1)$

$\therefore 1 j$

1

79

79

$=$

$2 \therefore$

2

99

99

1

1

2

$\because 7$

77

1

1 3

16

10

1.3

$\therefore$

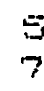

10

3

2

10

12

13

1.3

CWSEFWEF

WEVDENEVEF, WINTOH: WEYDEMEYEF, WHATOH

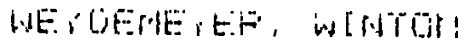
HE, DENE, EF, UAMTMI:

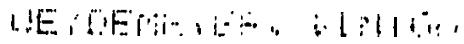

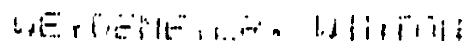

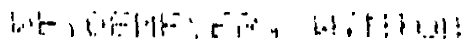

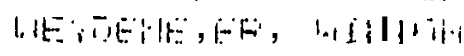

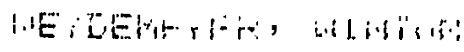

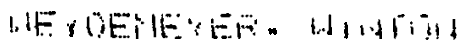
WE RUEHE rEF, IJUTOI!

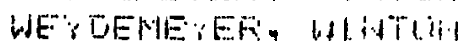
WEYDEHFVE, LAMTOI!

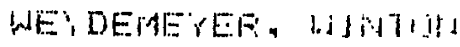

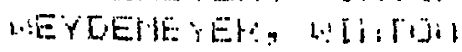
WEYDENEYEF, WINTLW WEYDERTYEF, WINTO! WEYDESHEYER, WIHTOW LEYOEMEYEF: CIINTÜN WE YDEWEYER, WIWTON LEYDEMEYEF: , WI WTOW WEYDEMEYEF, WITITOH: HEVDEMEVEF" , UINTUM BRCIUKSS, JAMES WECKLWEFTH, DICC: CUUEY, FCIRE COUUE, Fíte i.Jith nowdid Litilisuldu!

CFOSS \& LOUH:

WEY DEMEYEF, WLITTOH UNHENOLW II Hinolit!

FLATH, DEHHI:S

CROSS , FLATH, VNOCH E CROSS, FLATH , KNOCK: HNOCHE, EROLWW, EFOSS

EO GN, DAN EY E . TINA EI ZEUAREFA FEES. BY JWI IF IEUFEFA FES . EY IOHH EI

JON\&: El.. 、 CHHLL:

ILIV: EL. $\because 1 .+1101$

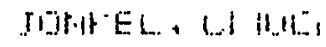

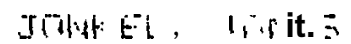

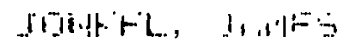

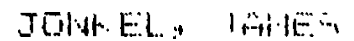

JOHN EL , IRIIIE:s

STUNE. GHEFTTRIN

STONE. SHEFILIMU

STORL, SITEFL Ü\%l

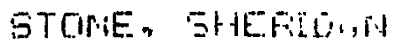

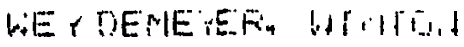

$$
\text { i i i it - j }
$$

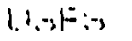

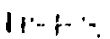

II

II'at'? 


\begin{tabular}{|c|c|c|c|c|c|c|}
\hline تَّ & 3. & $\begin{array}{l}1 \Rightarrow m \\
1 \% \%\end{array}$ & 三 & $\ddot{i}$ & 1.3 & ing \\
\hline 5 & 111 & $1 \theta^{n} \rightarrow$ & $\because$. & 11 & כ & 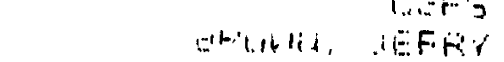 \\
\hline 5 & 1,1 & $1 \%$ & 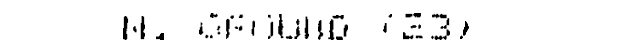 & (i) & 7 & 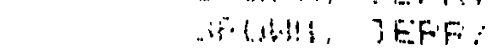 \\
\hline 5 & 12 & 1979 & SEI + $\dot{\therefore}$ & 1. & 10 & IISF \\
\hline $\bar{T}$ & 15 & 1979 & 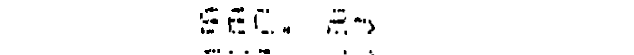 & 1 & $\therefore$ & $.1:-5$ \\
\hline & & 1530 & Ean & $\because$ & 3 & $15 F 5$ \\
\hline & & 1980 & 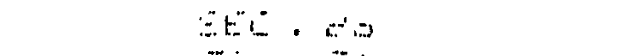 & i & 13 & , \\
\hline+ & 4 & 1791 & 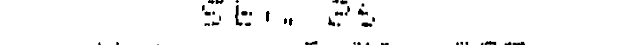 & 1 & 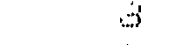 & 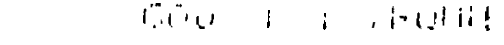 \\
\hline 1 & $\therefore$, & $\mathrm{i} \cdot \overline{\mathrm{i}} \mathrm{i}$ & $1,441,,,+13 \times 13=46 ?$ & ; & 1 & 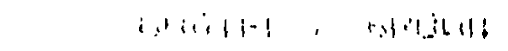 \\
\hline : & 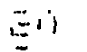 & 1981 & $\because \because \cdots$ & $\ddot{z}$ & $\therefore$ & Givilel : ris on if \\
\hline-4 & 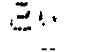 & j舟 & $\because \because 1, \therefore=$ & । & $\because$ & 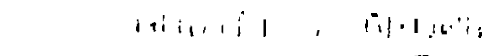 \\
\hline. & 3 & 1933 & $\cdots+i \quad, \quad, \cdot$ & $\because$ & 3 & 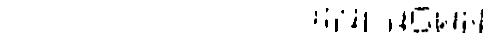 \\
\hline .1 & is & 10 & 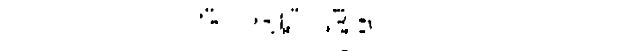 & 1 & $?$ & I ii $: 4,41,16 !$ \\
\hline-9 & $1 \cdot \%$ & 140 & 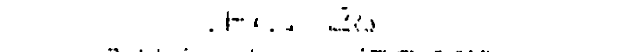 & 1. & 7 & 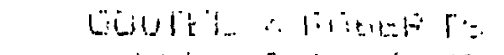 \\
\hline$\therefore+1 . \mathrm{L}$ & & 1.789 & 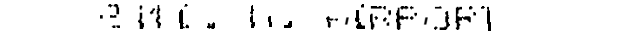 & $2=$ & 1 & HELIH,[LH, G,YE. \\
\hline 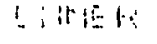 & & 178 & $-i+16 t=1-a r$ & 8 & FLOEI: & EHTIE, BETHGE \\
\hline. & 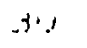 & 150 & $i \cdot i .4 \quad \cdots$ & 1 & 5 & O \\
\hline$\because$ & is & 1950 & '.t. 1 , $=0$ & 1 & $\because$ & Guilo a E E \\
\hline$\because$ & 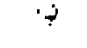 & $: \because n i$ & 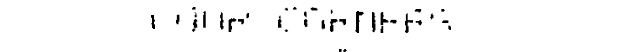 & $\because$ & $\ddot{y}$ & 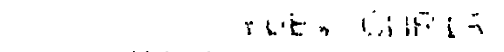 \\
\hline 4 & $\because 1$ & $176 \%$ & $-\operatorname{tat} \cdot \because n$ & 1 & $\therefore$ & TCUHG E HABEFI \\
\hline r & $1 . \cdot$ & $: 5$ & $\therefore \ldots i, \quad \bar{\cdots}, 4$ & 1 & 3 & 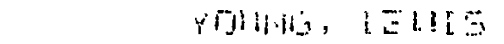 \\
\hline .1 & $\dot{\lrcorner} \dot{\exists}$ & $173 \%$ & 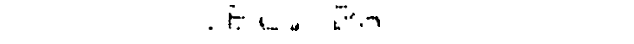 & 1. & + & 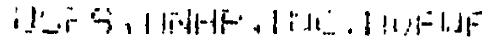 \\
\hline$\because$ & i & 1987 & 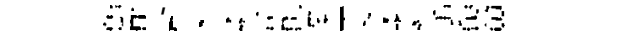 & +4 & 1 & 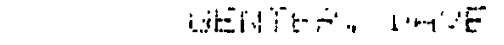 \\
\hline 5 & $\dot{\Delta}$ & $195 ?$ & 等 & 1 & $11 *$ & GENTEF, LAOE \\
\hline$\overline{1}$ & $a$ & 3797 & $\cdots: i \quad r$ & 1 & 3 & OENTEF, TRHE \\
\hline 5 & 7 & 1997 & $\therefore L 1, \ldots$ & 1 & 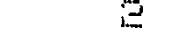 & หÜU.4E, LEHT \\
\hline$\pi$ & $=$ & 1607 & 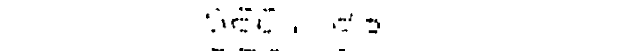 & $\mathrm{t}$ & $3 *$ & GENGEHA GHEE \\
\hline 5 & 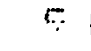 & 1737 & $\because E, \because$ & 1 & 1 & $\because$ GUIL $1 . E H 1 \%$ \\
\hline : & $L=1$ & $1 \div 8 \%$ & 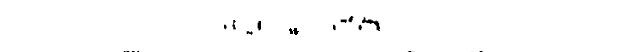 & 1 & 1 & rounin , RE \\
\hline$\dot{r}$ & $\cdot 1$ & $1.79 \%$ & 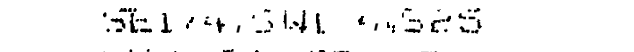 & $8 y$ & is & HLEEFT'= IIU \\
\hline$\therefore$ & $1=$ & 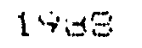 & 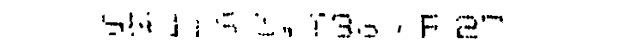 & $7 \%$ & $1-10$ & 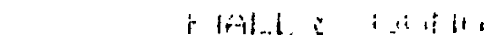 \\
\hline 4 & 31 & 1. & CLLU & 1 & $\ddot{3}$ & 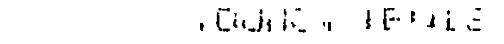 \\
\hline +t & 11 & 1.783 & 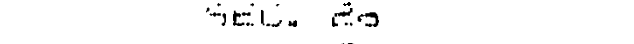 & 1 & ت & Hr+LLELf:119E; \\
\hline i & 10 & $13 \mathbf{a}$ & $\because E, \quad \because \theta$ & 1 & 3 & 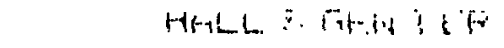 \\
\hline-1 & $\therefore$ & 1793 & 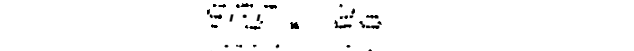 & 1 & $\Sigma *$ & 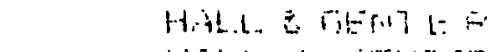 \\
\hline+ & & & $\therefore E-20$ & 1 & $\therefore$ & WHILL : GFHTEF \\
\hline.- & 15 & 1989 & $\because 5 E-20$ & I. & $\exists$ & it: B L L LEITE: \\
\hline 4 & $\because 2$ & 1569 & هי: & 1 & -1 & 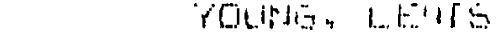 \\
\hline$\rightarrow$ & $\because \because 3$ & 199 & $\because n, E$ & 1 & $\therefore$ & 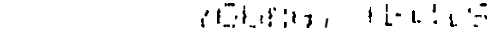 \\
\hline$\cdot 4$ & 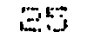 & 1589 & $=E[.20$ & 1 & 1.5 & 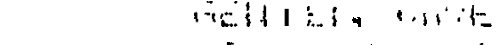 \\
\hline 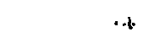 & $\sigma$ & 1.28 & $5=0.23$ & $i$ & 3 & 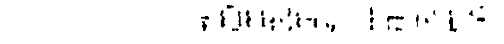 \\
\hline 5 & 2 & 1458 & stit. 3 & 1 & 8 & 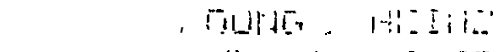 \\
\hline 5 & $1 \ddot{3}$ & 1758 & 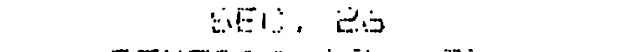 & $\mathbf{i}$ & 1.7 & 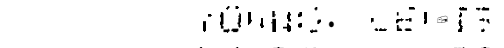 \\
\hline$\because$ & 17 & , 783 & 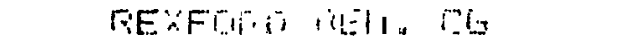 & י人 & 1. & 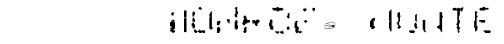 \\
\hline$i$ & $\exists$ & 1989 & WÜi i $\because \because$ FiriniLH $\cdots$ & $\Rightarrow$ & I & 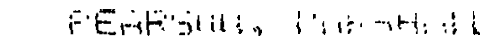 \\
\hline 1 & II & 1997 & 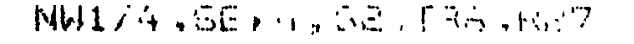 & 79 & - t & $\mid i_{1}+\|\| H_{1}, \quad i i_{1}$ \\
\hline 1 & $\because 1$ & 1789 & 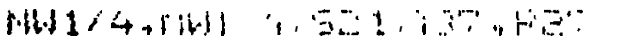 & $\because$ & $\because$ & 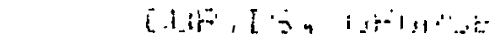 \\
\hline 1 & $=7$ & $1=0 \%$ & , & 59 & $\cdot r$ & ilend.t: \\
\hline 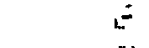 & $\therefore$ & 1987 & 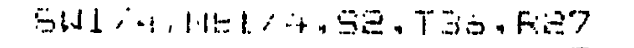 & $8 \overline{4}$ & -+ & H+illlE: \\
\hline 2 & 17 & 1797 & 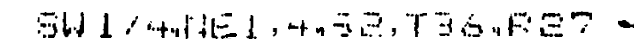 & $\therefore 07$ & $\therefore$ & PliNhER TH \\
\hline$\Xi$ & $E \%$ & 1789 & 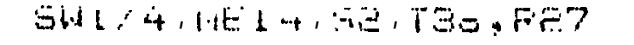 & 'י⿻ & $\therefore$ & 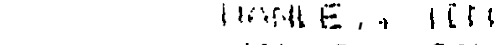 \\
\hline$\exists$ & 1 & 1985 & 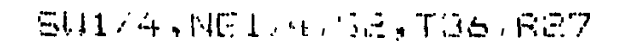 & 90 & 1 & Whille:, rill \\
\hline 3 & i & 1797 & $5 W 1 / 4+n ! E 1+, B, T \geqslant 0, F, \equiv 2$ & ; & $\equiv$ & IH-1 :LEs, 11,1 \\
\hline 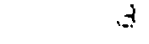 & $\dot{i}$ & 1797 & 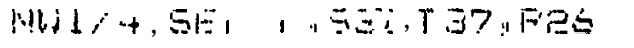 & $4 \overline{7}$ & 9 & 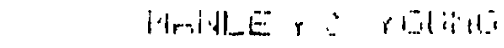 \\
\hline 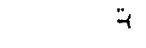 & . & 1799 & 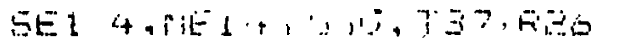 & $=7$ & E. & 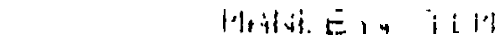 \\
\hline 3 & $\dot{0}$ & 1.787 & SE1, & $\vec{\nabla}$ & 6 & 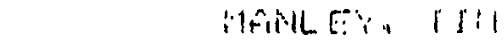 \\
\hline$i$ & b'. & $1 \cdot 3$ & $\cdots+2 \Sigma^{\prime}=$ & 1 & 3 & 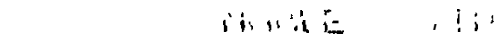 \\
\hline$\because$ & $1 "$ & 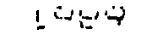 & $31, . \quad \therefore$ & 1 & $\therefore$ & 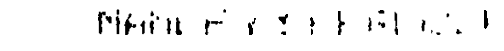 \\
\hline$\ddot{y}$ & $\therefore 3$ & $1 \% 87$ & $-6 r^{5} \cdot \because$ & 1 & 11 & 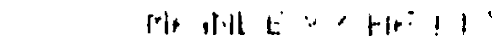 \\
\hline
\end{tabular}


SEL . 5 \&

GE. E

EE: $\mathrm{Ba}$

Nic. 3

SEE.

Bis

S月⿺

SEC .

SEC . :

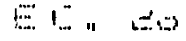

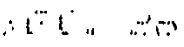

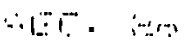

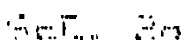

$\because \therefore, \because-\because$

aril a

$\because 1:-20$

i $\therefore$, ' :

,,,$- \therefore$

$\because \quad \therefore$.

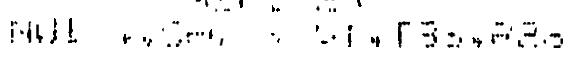

1
1
1
1
1
1
1
1
1
1
1
1
1
1
1
1
3
1
1
$\therefore=$

MARTE: \& FEFFUEZ

MANLEY, GESTEE, YGLA

MAOULEY, GETITER, YGMU

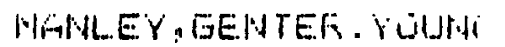

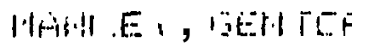

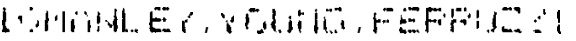

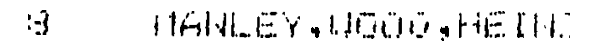

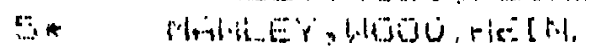

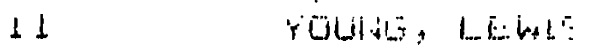

13

14

I!

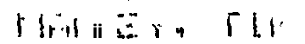

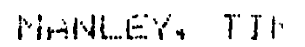

18

$\because$

$\therefore$

2

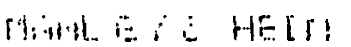
Mritle: ril

W atlo

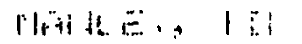
HOAFICI!, SIE.E 
APPENDIX H

The financial analysis of the Bear Creek canyon proposed scenic easement by the

Department of State Lands. 
Analysis of Financial Value of Bear Canyon Viewshed

This summanzes Procedures and results for an analysis of the value of a scenic easement on State Lands in the Bozeman viewshed.

The scenic rights to the Bozeman viewshed are considered an alternative use of State Lands. and must be evaluated against the State's planned management for timber production. The State must receive as much compensation for selling scenic rights as they would expect from growing and harvesting timber so our trust objective can be meet.

Several steps were necessary to estimate the value of the scenic rights in the Bozeman viewshed:

1. Identify the viewshed:

The viewshed was identified as the area visible $f \quad r \quad o \quad m$ the steps of the Museum of the Rockies (see attached map \#1). The areas visible were determined by using aerial photos, USGS topographical maps and profiles run from the steps of the museum through the state land ownership. The profiles are a plot of the vertical relief versus the horizontal distance. They were plotted to determine the parts of Gear Canyon that are visible from Bozeman.

\section{Stratify the viewshed and Compile Timber Inventory Data:}

Using stands maps from a 1976 inventory project and the proposed sale map, we visited each stand in the viewshed. Stand boundaries and often stand types and stocking were updated when necessary. The stand was then assigned a number. Upon visiting the stand a variety of stand and site data was collected. The stands were later drawn on topographical maps and area was estimated. In addition, in certain stands plots were taken to augment plot data from the 1976 project. The plots were randomly located in stands. Tree data was collected to meet the data requirements for the SPS timber growth model (Arney 1987). Site index was calculated for each stand. The final results were a stand map of the viewshed and data describing each stand. The stands were grouped into primary strata based on several variables:

Species code - the predominant species forming the stand ( D for Douglasfir or LP for Lodgepole pine);

Stand size class - Sawtimber stands are > 10 percent sawtimber crown density, poletimber stands are $<10$ percent sawtimber crown density, and seedling sapling stands;

Stocking - poorly stocked stands are 10-39 percent crown density, medium stocked stands are 40-69 percent crown density, and well stocked stand are $70+$ percent crown density)

Stocking of the sawtimber component - for all stands that have $>10$ percent sawtimber crown density, record the code that best describes the stocking of the sawtimber com ponent. 
For each strata a data file was built from inventory plots found in the strata. The older plots were updated to the cresent using SPS. The new and old plots were averaged together.

The average board foot volume per acre was estimated for each strata. Based on these volume estimates strata were grouped together when the volume per acre and species composition were similar. The end result was an SPS file for each strata that contained a stand table (Species, Diameter at breast height (DBH), ht. crown ratio, and DBH-age. These files will be used to project stand yield over time by strata.

3. Develop management alternatives:

Two management alternatives were evaluated for each strata:

A. Timber production:

Our current direction is to manage a portion of our lands in the Bozeman viewshed for timber production. This option results in road building and timber harvests that will be visible from Bozeman The current direction was based on the Bear Canyon Management Plan and personal communication with our field foresters and managers. The proposed management direction can be divided into two parts; 1) the stand level prescription and 2) the unit plan for harvesting the timber (ie timber sales).

1) The strata prescriptions were developed as a function of species composition (Pure Douglas-fir, pure lodqepole, or mix of lodgepole (LP) and Douglas-fir (DF)) and slope. It was assumed slopes less than 40 percent would be tractor logged and slopes greater than and equal to 40 percent slope would be cable logged (see attached map \#2). The following are the general prescription guides that were applied:

$\begin{array}{cll}\text { Spec i es } & \text { Slope Regeneration System } \\ & & \\ \text { DF } & <40 \% & \text { Seed tree - She1 terwood method } \\ \text { DF } & >40 \% & \text { Clear cutting method } \\ \text { LPP and DF } & <40 \% & \text { Seedtree - Shelterwood method } \\ \text { LPP and DF } & >40 \% & \text { Clear cutting method } \\ \text { LPP } & <40 \% & \text { Clear cutting method } \\ \text { LPP } & >40 \% & \text { Clear cutting method }\end{array}$

The Seed tree - Shelterwood method consisted of removing of all but approximately 30 seed trees. The remaining seed trees were removed after 20 years. The clear cutting method is the removal of the entire stand in one cutting with reproduction coming from natural seeding (serotinous cones or adjacent stands).

2) A plan for timber harvest activity and timing was estimated for the vi ewshed. All the stands in the viewshed were divided into 8 harvest units. A proposed roading plan was estimated from a USGS topographical map (see attached map \#3). The harvest plan for 6 of the units is harvest $25 \%$ of the area every 20 years starting in 20 years. One unit and a stand from one of the first six contains the proposed Bear Canyon timber sale which was assumed to be harvested in the current year. The 
last $\mathrm{u} \mathrm{n} \mathrm{i}$ t which is located in section 6 required only 2 e $\mathrm{nt}$ ries at 20 years a $n d 60$ years.

B. Viewshed - No timber will be harvested under this opt ion, thus no revenue will be generated.

4. Estimate financial returns:

Financial returns were estimated for each strata under each of the timber management alternatives. The procedure used was:

1) The area in the current Bear Canyon timber sale was separated into two strata:

2) Growth projections were made using SPS based on assumption regarding regeneration system, initial stocking level and early stand growth. Current timber harvest volumes were estimated only for the proposed timber sale along with values 20 years hence, 40 years hence, 60 years hence and 80 years hence;

3) The total value for each acre was estimated based on the value of the current stand plus the value for all future stands. Values were estimated using Fast computer software that combines a timber growth model with a financial analysis package. The timing of the timber harvest and harvest method for each strata were based on requirements of the silvicultural prescription and the timber harvest plan;

A) Existing stand - the net present value (NPV) for the current stand was calculated based on an average stumpaqe price, projected volumes per acre and treatment costs. Stumpage price was trended into the future. Hazard reduction was treated like a logging cost. Roading costs were estimated on a per acre basis;

8) Future stands - the land expectation value(LEVI was calculated for each stand as the value of an infinite series of rotations from a piece of bare land. This was based on our expectations for regeneration, stocking, future growth, costs, and stumpaqe projection. The stumpage price was reduced by $\$ 1.00$ before trending to account for future development costs. One set of regeneration assumptions (timing size and stocking) were used for all management prescription;

4) The value per acre (NPV + LEV) was calculated for each planned entry into the unit. The stand value was calculated by averaging the strata value per acre for the different harvest entries. The proposed timber sale stand value per acre was not averaged because they were only one harvest time consider;

5) Value total for harvest units were calculated by multiplying the average stand value by the number of acres in the stand and summing across all stands in a unit. This value was reduced by the total initial development cost for the unit in order to estimate the net return to the trust; 
5) The total return to the trust for the area in the viewshed is the sum of the eiqht units.

5. Estimated viewshed valu es:

Our viewshed values were determined by estimating the difference between the financial value of the acreage with and without timber management.

The estimated value of acquiring the scenic rights for the Bozeman Viewshed with no timber management is $\$ 409,700$. 


\begin{abstract}
APPENDIX I
The Department of State Lands scenic easement on the Soup Creek Ranch.
\end{abstract}

| - | 


\section{STATE OF MOATINA \\ DBPARTYRIT OF STATE LANDS STATB LAND USB LICBMSB}

THIS AGREEMENT, entered into by the State of Montana, Department of State Landa, herein referred to as the licensoe and, herein referred to as licensee, WITNESSETH:

Date this agreement takes effect: June 1, 1989.

Land located in: Those portione of Lake County as described and bounded in Exhibit "A, " attached hereto amadea part hereof.

Total number of acres: 7.03 more or less, Belonging'to this license.

\section{Date of Expiration : February 28,1999}

This license is granted solely for the purpose of a scenic area for licensee.

In consideration of the rentals to be paid and covenants to be performed by the licensee, its administrators, and agents, the licensor hereby agrees to allow the Licensee to use the above-described land fur the purposes above set forth.

This license is granted for a term of ten years and is subject to the terms, conditions and restrictions set Forth herein.

IT IS MUTUALLY UNDERSTOOD, AGREED AND covenantet BY AND BETWEEN THE PARTIES TO THIS LICENSE A3 FOLLOWS:

1. The liconsee shall pay to the licensor an annual money rental as specified in Section Thirteen (13). Failure to pay each year's rental on or before due date automatically cancels this lease. However, the lease may be reinstated within 30 days after cancellation upon payment of the amount due plus an amount equal to that rental,

2. All payments required by thislicense shall be made to the Department of State Lands, Forestry Division, 2705 Spurgin Road, Mlssoula, Montana 59801.

3. If all rentals due the State under this license have been paid and the terms of this license have not been violated, the licensee may make application to the licensor, within thirty (30) days prior to its expiration, for an additional term not to exceed ten(10) years at such rental as the licensor may determine is a fair return to the State; should the licensor in its discretion decide it is in the best interests of the State not to renew this license and notify the licensee at least six (6) months prior to the expiration of the licenseof such decision, the licensee shall have no renewal rights.

4. This license is strictly limited to scenic purposes only. The licensee shall not open any mine or quarry or work or dig any ore, coal, gas, gravel, sand, stone, gems orother non-minerals from any nine or any stone quarry, pit or diggings situated on said land whether such mine, quarry, pit or diggings was open at the date of this license or not. The licensee shall not cut, remove, use or destroy any timber or standing trees upon the land under this license and shall not allow or permit any other person to cut, use remove or destroy any such timber or standing. trees, unless-such person is authorized in writing by the licensor to do so. The licensor 


\section{retains the right to grant permits for uses not in conflict with the license.}

5. The licensee shall permit licensor, its agents and employees, users of statsForest lands and purchasers of State Forestproducts, free ingress and egress across the premises heroin described, when so authorized by the licensor.

6. Reprosentatives othe State Historical Society of the State of Montana shall at all reasonable times have the right to enter into and upon the subject property for the purpose of carrying out duties assigned.

7. The licensor may cancel this license if the licensee commits fraud or misrepresents factsto the licenswbich, if known, would have had an effect onthe issuance of thelicense, uses the land for any purpose not authorized in the license, or violates the term.of the license or for any other reason provided by law. The licensee of a cancelled Lease or license shall not be entitled to any $r$ efunds orexemptions from any payments due to the state. License cancellation, except for nonpayment of rent, is subject to appeal as provided in Section 77-6-211, MCA.

8. The licensee shall have the n.m. to assighis license to another party upon the same terms and conditions as those under which helicenses it from the State, provided that no such transfer shall be legal until a copy thereof has beenfiled with the licensor and approved by the Commissioner of State Lands. If a licensee subleases State land on tans less advantageous to the sublessee than the terms given by the state or subleases State lands without filing a copy of the sublease with the Administrator, Forestry Division, and without. receiving his approval, the Administrator shall cancel the lease subject to the appeal procedureprovided in 77-6-210 and 77-6-211, MCA.

9. The licensee may request the right to surrender and relinquish the license in whole or in part, by writing to the licensor at least thirty (30) days prior tothe termination of any rental year. The commissioner of state Lands may grant or deny the request and may condition the right to surrender and relinquish upon the payment to the state of reasonable damage caused by the surrender.

10. Special Conditions; Terms, Restrictions and Reservations:

A. The licensowill retain the ownership of all of the above-described land and reserve all rights to timber management, gravel excavation, water rights, mineral rights including hydrocarbons, or any other right not specifically granted to the licensee by this license.

B. The licensoragrees not to harvest any timber on the landunder this license for the period of the license unless agreed upon by both the licensee and the licenser. The Department may not remove trees which are diseased or are infested by insects and which pose an immediate threat to adjacent timber.

c. It is understood and agreed that the licensee shall assume all risk and indemnify and hold harmless at its expense the licensor against any claims, loss, cost, legal actions, liability or expense on account of personal in-jury or the death of anypersons whomsoever, or damage to 
or destruction of any property whatsoever, due to occurrences on the subject property. Licensee aqrees to insure the promises as to property hazards by adding the subject property to his ranch insurance.

D. The licensorretains all rights not specifically granted by this license.

E. Annual rental fee will be $\$ 60.00$ per acre per year on 7.03 acres, which amounts to $\$ 421.80$. Such payment shall be in advance and due thirty (30) days after approval in 1989 or before. February 28 th of each year thereafter.

11. The liccnsor and licenseeagree tocomply withall applicable laws and regulations in effect at The date of this license, orwhich may, from time to time, be adopted, and which do not impair the obligations of this contract and which do not deprive the licensee of any existing property right recognized by law.

12. The licensee agrees to take all reasonable precautionsto prevent and suppressforest fires.

13. The licensee agrees to report immediately to the licensor any trespassing livestock or timber cutting observed upon these premises.

14. The licensee agrees, at his own expense and cost, to exterminate noxious weeds and pests to the same extent as a private owner or state Lands is required to do. In the event that more than one license is Issued on the tracts described herein, the licensee agrees to share costs and expenses related to noxious weeds and pests proportionate to each licensee's use.

15. Licensor shall strictly prohibit, the cutting of timber and any land disturbance on the subject property. Provisions to this effect shall appear in any contracts, permits, or document 6 relating to use of state lands adjacent to the subject property.

16. The making, execution and delivery of this agreement by the licensee has been induced by no representations, statements, warranties, or agreements other than those herein expressed. This agreement,embodies the entire understandings, written or oral, in effect between the parties, relating to the subject matter hereof except as may be hereto attached. This instrument may be amended or modified only by an instrument of equal formality signed by the respective parties.

17. All covenants and agreements herein set forth between the parties hereto shall extend to and bind thrir successors, assigns and legal representatives. 


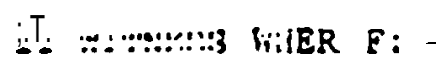

IILENSOR I.ICE - . EE

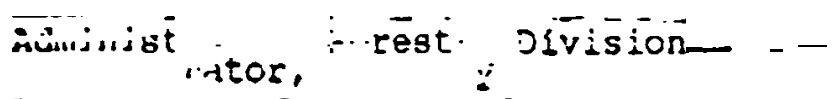
Desartment. of $S^{\prime}$ te Lands

Date: $-\quad--\quad-\quad$ Date: 
Beginning AI THE NW corner of the 5Nisw: Saction 18 T24"-R17W, MPM, Lake County, thence on anazimuth of $90^{\circ} 635$ feet to a point which is the beginning of segment \#1 ofthis assement thence a strip of land 2 chains wide on an azimuth of $253^{\circ} 325$ feethence on an azimuth of $\mathbf{2 0 8 ^ { \circ }} 675$ feet to a point which is the end of segment $\div$ : of this easement, thence on an azimuth of $180^{\circ} 624$ feet to the sectioncorner common to Sections 10 and 19 of T24N-Rl7W and Sections 13 and 24 of T24N-RlBW which is the beginnizg of segment $\# 2$ of th is easement; thence a strip of land 2 chains wide on an azimth of $270^{\circ} 1,32 \mathrm{C}$ feet to a point which is the end of segment \#2 of this easement.

Total acreage of segments 1 and 2 is $\mathbf{7 . 0 3}$ acres. 
APPENDIX J

The Rocky Bar 0 Ranch conservation easement.

J-1 


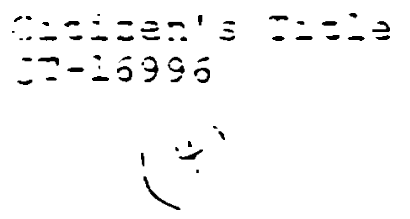

$86365 / 5582$

Parcel 1 and 2 - Purchase

\section{DEED OF CONSERVATION EASEMENT}

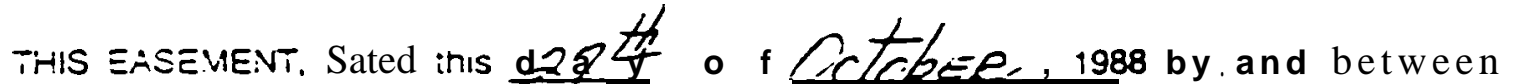
FOCMY BAR 0 IANCH. INC.. a Mcntaria Corcoration of Columbia Falls. MT 59912 hereinater called the Grantcr, and :Te UNITED STAIES OF AMEFICA, whose address is Washington, DC 20013. hereinafter called the Grantee:

WHEEFEAS. Puslic L3w S0-5:2 (82 Siat. S06), as amended, provides for the establishment of a Wild ano Scenic Fivers Sysiem, and cesignated portions of the Flathead River System in Montana as a component of the National Wild and Scenic Rivers System to be administered by the Secretary of Agriculture as pan of ine Naticnal Forest Sysiem, and

WHEFEAAS. Pudlic Law 93.205 the Endangered Species Act (87 Stat. 884) provides for conservation of ecosystems upon which threatened species depend,

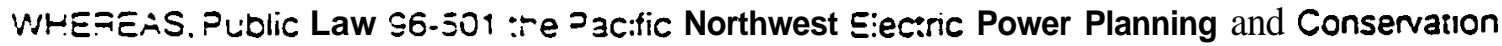
Act (Ncrinwesi Fower Ac:) provices icr ine protection. mnigation, and enhancement of fish anc wilclife rescurces atifec:ed by ithe cevelofment and operation of Columbia River Basin mydroelecinc facilities. and

WHEFE:S. : the Grantor :s the owner of certain land both within and outside the estaclished touncaries of the Fiathead Fiver component of the National Wild and Scenic Rivers System. tocated in Fiatnead County, State of Montana. said land being appurtenant to other lands of the Grantee and affecting the public benefits froviced by the Federal land, and

WHEAEAS. the Grantor's land suppons significant communities of native plants and provides important habitat for native wilclife including grizily bears and black bears, spec:es icentitied icr protection in the Columoia Fiver Basin Fish and Wildlife Program. and

WHEREAS, the Grantee. by the United States Cepartment of Agricutture through the Forest Service, or its assigns, desires to administer such land pursuant to the Wild and Scenic Aivers Ac: and the general statutory authorities relating to the National Forest System and to provide for and protect the ratural, scenic. recreational. and other values for which this river was designated, and io prevent developments that will tend to mar or detract from these values. and to that end exercise such reasonable controls over the land within the areas described herein as may be necessary to accorriolish sucn cojecives. and

WHEFEAS, the Grantee cesires to administer sucn land under the authonty of the Endangered Species Act which lists the grizzy bear as a threatened species and allows for the conservation of ecosystems upon which the threatened species cepend.

WHEREAS, : he Grantee also desires to administer such land for the purpose of tre Northwest Power Act for ine srctection. mitigation. and enhancement of ish and vilclife resources identfied in the Columbia River Fisin and Wilclife Program. 


\section{$55.565 / 5580$}

NOW THEREFORE The Grantor FRand in consideration of the sum of Four Hundred Fifty-Two Thousand Five Hundred Dollars. (S42.500). the receipt of which is hereby acknowiedged and in further consideration of the covenants herein contained. does hereby grant and convey unto the Grantee and its assigns a perpetual estate and easement in the following-described lands in the County of Flathead. State of Montana, to wit:

Parcel 1

T. 34 N.. R 20 W.. P.M.. MT..

Sec 18. Lot 9 . WI/2SEl/4NWI/4. W1/25I/2SEI/4NWI/4. NW1/4SE1/4. NE $1 / 4$ SW $1 / 4$ that portion of lot 10 and SE1/4SW $1 / 4$ tying north and east of the North Fork County Road.

T. 34 N.. R. 21 W.. P.M.. MT.. Sec. 13. Lot 1. NWI/4NEI/4, SEI/4NE1/4, mat portion of the NEI/4SEI/4 tying north and east of the North Fork County Road.

Subtotal Acreage: 311.45 acres

Parcel 2

T. 34 N.. A. 20 W., P.M. MT.. sec. 17. Lots 6. 7. and a and SWI/4SWI/4: sec 20. Lot 2 and NW1 $/ 4 N W / 4$.

Subtotal Acreage: 150.54 acres

The above-decribed property contains 461.99 acres. more or less

The acquiring agency is the Forest Service. United States Department of Agriculture.

Grantor and Grantee do hereby covenant and agree for themsetves, their successors and assigns .that they shall use and restrict the use of the easment area as set forth hereafter. itbeing mutually agreed that such use. or restnction thereot, shall run whth the land, and be to the benefit of the emire river area and such other lands of the Grantee which are sinusced within said area by fostering and enthencing the Grantee's goal of presenving the scenic, recreasional and willite quatities (inctuding the open space and riparien values for grieaty beer habital) in accordances with the Nortumest Power ACr, the Wid and Scanic River ACC and the Endangered Species Act

\section{USE BY GRANTEE:}

The Grantee its authorized representatives and/or assigns, is hereby granted me right to go upon me land described in this easement for the following purposes

A to inspect for viotations and to acminister this easement. including the establishment and maintenance or corners celineating the easement area me Grantee. whenever feasible. snail notify any owner or tenant occupying the easement area of the impending inspecoon and shall offer that occupant an opportunity to accompany the Grantee on the inspection

3. At the expense of the Grantor. remove or eliminate any advertising displays. signs and biilboards. stored or accumulate junk automobiles and other salvage materials, junk. or debris which 


\section{$88365 / 5580$}

is net permitted by the terms of this easement. and is placed on the above-described land after the date of this easement.

C. To mark. cut. and remove any trees and shrubs which in the judgment of the Grantee endanger public Safety or retract from the aesthetics of the above described area, and to plant or selectively out or prune trees and Shrubs to restore or maintain the Scenic view and to implement disease prevention measures. these practices will be compatible with management ob]ectives for protection of grizzle bear habitat. The propery Owners shall be consulted prior to initation of such operations and less restrictive alternatives snail be considered. Any mercnantable umber so cut snall, unless otherwise agreed. ze cut into logs of standard lengths for cisoosal by the Grantor.

D. To cerform such other scenıc. aesthetic. hisiorical, fish and wildlife. sanitation. resicration or other work as. in the opinicn of the authorized representative of the Grantee. may be deemed necessary or cesiracle to protect and promcte ine natural and rec:eational cualities of the area The Grantor snall be consulted prior to initiation of such projects and the least restrictive alternative shall be consicerec in the event that ine Grantor feels the acivity may conflict with the nights and uses retainec by the Grantor.

E. To posi regulatory notices on selecied portions of the easement area for purposes of promoting the provisicns of this easement and the intent of the Wild and Scenic Rivers Act at its discretion to utilize with iescec: :o the puolic ihe general statutory authorities relating to the National Forest and Wild and Scenic Fivers in such a manner as it ceems aopropnate io carry out the purposes of saic Ac: Nothing in this clause is intended to abrogate the lancowners right to legally protect their property ur.cer State law.

Exceot as nctec. ac:ivities concucied by the Grantee under the above section shall be at no expense : 0 : the Grantor. Nothing rerein shall be construed as creating any duty on the pan of ine Grantee to undertake any of the acis cescribed above.

\section{USE BY GRANTOR:}

In return for the stated consideration, the Grantor assumes the following covenants and resiric. tions. These covenants and restncions are imposed upon the occupancy and use of the easement area by the Grantor, all successors and assigns, except that none of these covenants and restrictions shall be ceemed as controlling the rights and uses retained by the Grantor including any regular use of the land exercised prior to the acquisition of this easement unless such use is acquired by the Grantee. Except as otherwise provided by this easement, the costs of conformance with the terms of Part II of this easement shall be borne by the Grantor.

Where specific activities and uses are predicated upon approval or permission by the Secretary of Agricuiture or his duly authorized representative, such approval or permission may be withneic or concitioned by requirements necessary to preserve the natural values of the area Such requirements shall have the same force and effect as if stated in this instrument. Both the Grantee and the Grantor must repond :o requests for soecitic actwities within 30 days. Permission or consent will not be unreasonably withneld.

A. The easement area shall not be further subdivided. sold. leased or atherwise conveyed as smaller tracts.

3. The lands within the easement area shall be used exc!usively for domestic livestock grazing (except for :IC), hay farming, and tree growing purpcses. 


\subsection{0}

(1) The Forest Service has the authonty to preclude all domestic livestock grazing within 200 feet of the Flathead River by locating, erecting and maintaining fences.

(2) Spraying of herbic:ces. insecticices or other pesticides is prohibited withcut the written consent of the Secretary of Agncurture or his culy authorized representative which consent shall not be unreasonably withneld.

(3) Additional land clearing is generally prohibited in order to maintain the present balance of open and timbered areas. Additional land cleanng within 200 feet of the river is pronibited. Written consent is sequired pnor to any land clearing except that no permissicn is needed to remove brush and trees from existing hay fields and open pastures in accorc. ance with good farm practices. Existing pastures and hay fields can be maintaned in good forage condition in accordance wrih established range management practices inctuding reseeding and haying.

(4) Boneyards (accumulation of dead animals) will be prohibited to avoid attracting grizzly bears in a concentrated area.

C. me keeping of domestic livestock such as pigs, sheep, or goats is prohibited.

D. Man-made beehives are pronibited within the easement area

$E$. The lands within the easement area shall not be used for any protessional, industnal or commercial activities.

F. No commercial buildings. single or multi-family residential buildings, or other industrial or commercial buildings shall be placed on the easement area

G. There is specifically retained by the Grantor, all successors and assigns, the right to perform ordinary maintenance on all existing or permitted roads together with the right to replace. reburid. or substitute any road now existing wrth similar roads in subsiantially the same location.

H. Except as expressly provided herein. no portable structures or any other low quality, unatrac. tive structures will be constructed or moved into the easement area

l. No tents, travel trailers, or camping facilities of any kind except for those owned by me Grantor or its guests shall be placed or erected upon me easement area except as approved in writing by the Secretary of Agriculture or his duly authorized representative. Consent shall not be unreasonably withheld. Permanent tent frames. flooring, and sidewatls are not permited.

J. No dumping of trash, ashes. garbage. sewage, sawdust. or any similar unsightty or offensive material is permitted writhin the easement area

$K$ The Grantor, all successors and assigns. may harvest timber from the easement area subject to me following conditions:

(1) Within a 200 -foot-wice stro along ine main stem of the Flathead River. onty salvage harvesting of dead or down trees will be cermitec. This will be accomplished without new road construction.

(2) Prior approval of a writen logging plan must be obtained in writing from the Secretary of Agnculture or his duly autnonzed representaive. Logging plans will be develoced in 


\section{$58.265 / 5580$}

accordance wrth sound imcer harvesting practices and will be compatible wrth Current grizz!y bear haortat management guice!ines. These plans will be reviewed or modified and aoproved cunng annual easement area inspecion. Grantee shall respond to Grantor's frocosed logging plans wrtnın 30 days and such proposals shall not be unreasonably deried.

Permission to cut anc rem.cve trees is not needed in the following circumstances:

To cut cead :rees or :o remove hazardous irees for reasons of safety or to protect existing or atthorized imorcvements.

$L$ No irees cr shrucs and cirer natural vegetation within the easement area shall be pruned. removed or cestrcyed excect incse authonzed in wrting by the Secretary of Agriculture or his duly authorized representative-exceot as ctherwise permitted herein.

M. No pumsing facilities. diversion works, or ditches used for withdrawing water from the river shall be placed, used or maintained on the easement area

N. Archeclcgical or paleoriological explorations may be conducted only by the Grantee or as authcrized by a permn trom :re Secretary of Agriculture or his duty authorized representative. All specimer.s Or materials of archeological ar paleontological interest shall be the property Of ine United States.

O. No cermanent cranges in the general :opography of the lancscade or land surface including the rivertec shall be permined exceot for those caused by the forces of nature. The grantor may crill we!ls or :ay, ocerate, maıntan, recair. or remove water and sewer pipelines, concults, or drains kelow the surface of the easerrent area insofar as such activities do not permanently imoair $\mathrm{cr}$ rin the natural beauty of saic easement area and proviced the disturbed area is returned :o its former natural condition.

P. Except as ctherwise provided. no signs. billboards. outdoor advertising structures. or advertisement of any kind shall rerearter be erecied or mantaned wrthın the easement area One (1) on-premise sign not greater in size than 16 inches by 24 inches may Se erected and mantained to acvertise the sale. nire. or 'ease of the proderty, or to advertise the sale or avaliability of any goods, producis, or services on the land: one additicnal sign of the same size may be erected and maimained to designate the owners or name of me property. In addition, me Grantor may erect and maintain appropnate signs as necessary to indicate that portion of the easement area which is not cpen to public entry. All signs restricting public entry shall not exceed 5 inches by 7 inches in size. shall be ct earn-ione colors and shall be placed so they are not readily noticeable from the iver or arterial roads.

Q. When acproved in advance by the Secretary of Agriculture or his duly authorized representative. cil. gas or mineral excicration, extraction or other related acivity may be permined, susject to acolicacle State law. on the easement area if sucn acivities can be screened from public view and such acivities would not degrade water. 'Nilalife or scenic resources. Aoproval shall not be unreasonacty cenied and less restncive alternatives snarl be considered.

R. The introduction of nonnative fish soecies in pudic or private waters within the easement area is stncily pronibrtec.

S. All wetland areas wil be protecied from disturbances. such as filling or draining. which would destroy their riparian qualries. 


\section{$55365 \angle 3580$}

T. The Grantor acknowledges that a collection of base-line data and documentation of existing land use practices for long-term monitoring purposes will be incorporated in an Administrative Plan and agreed upon by the Grantee and the Grantor. The parties acknowledge that sard collection of base-line data is cesigned to establish the condition of the property subject :o this Conservation Easement at the time of this grant.

With respect to the provisions in this easement which require approval in writing by the Secretary of Agriculture or his duly authorized representative. the Grantee agrees to respond to all Grantor's requests in a prompt manner.

\section{PUBLC ENTRY:}

The granting of this easement is not intended to permn or in any way give the public the rignt to enter upon said land for any purposes. Where needed, the Grantee may erect appropriate signs indicating the easement area is not open to public entry.

TO HAVE AND TO HOLD the herein described scenic easement and rights unto the Grantee and its assigns forever. The said Grantor hereby covenants that it. all successors, executors, administrators, and assigns, shall warrant and cefend unto the Grantee and its assigns, the quiet and peaceable use and enjoyment of the herein granted easement against the lawful claims and demands of all persons whomsoever. This grant shall be bincing upon the Grantor, all successors, administrators, executors. and assigns. and shall run with and construte a servituce upon the abcve-described land.

IN WITNESS WHEREOF, the Grantor has caused these presents to be executed in its name and its corporate seal hereunto affixed the day and year first above-writien.

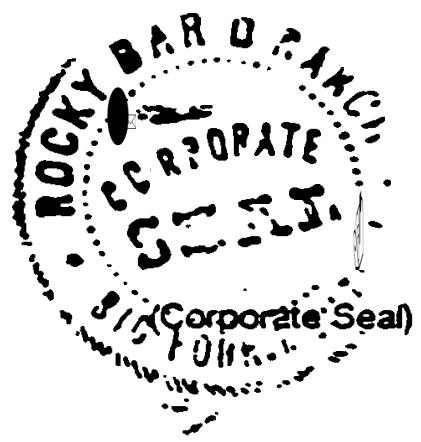

ROCKY BAR O RANCH, INC.

\section{ATTEST:}

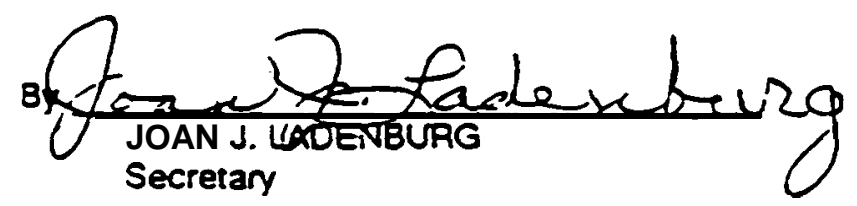




\section{ACKNOWLEDGEMENT}

\section{STATE CF MCNTANA)}

County of Fiarnead )

ss.

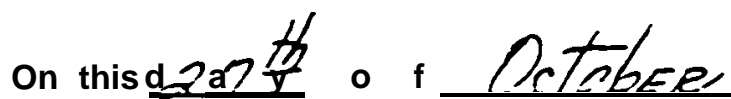
, 1988. before me. the undersigned. a Notary Public in and for the Stare of Montana. personally appeared C. T. Ladenburg and Joan J. Ladenburg, known to me to be the President and Secretary of the Corporation that executed the same.

IN WITNESS WHEREOF, I have hereunto set my hand and affixed my official seal the day and year first above-written.
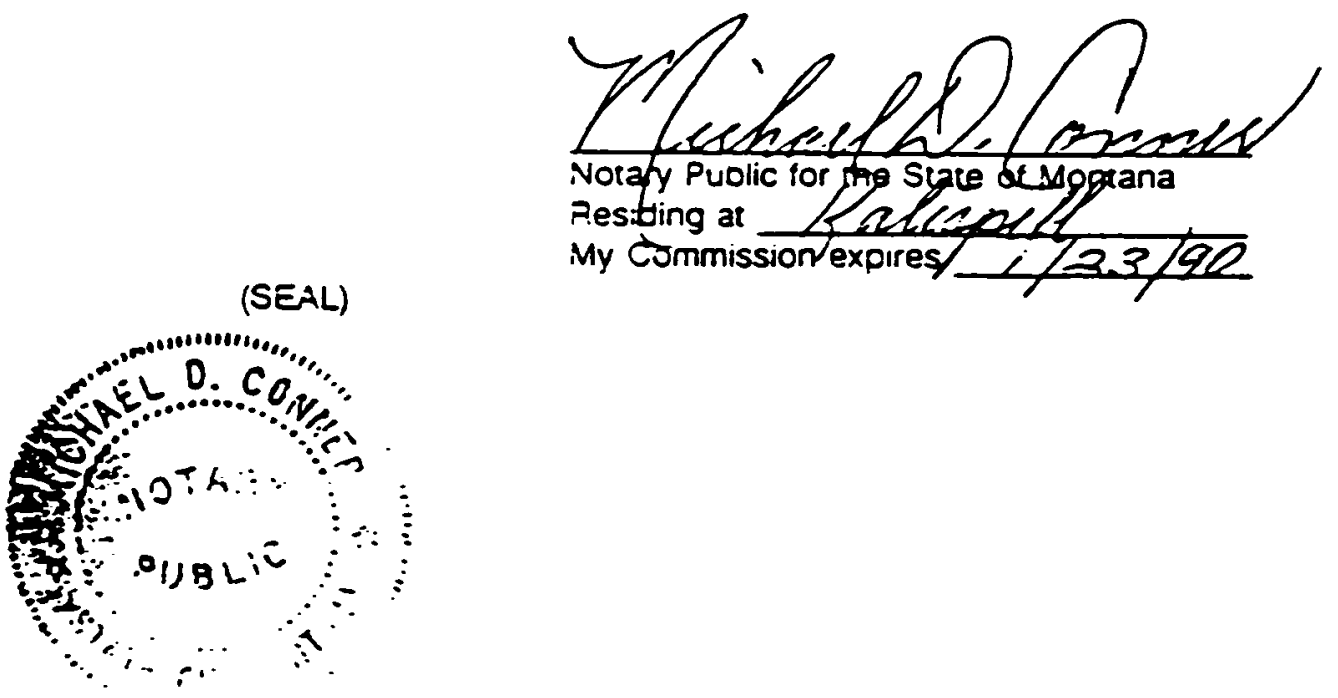

Return: Rocky Bar 0 Ranch, Inc.

St a r Route

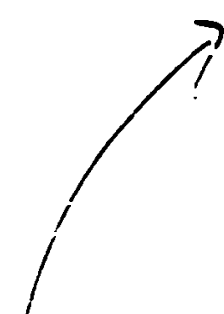

Columbia Falls, MT. 59912

Recorded at the request of Cti

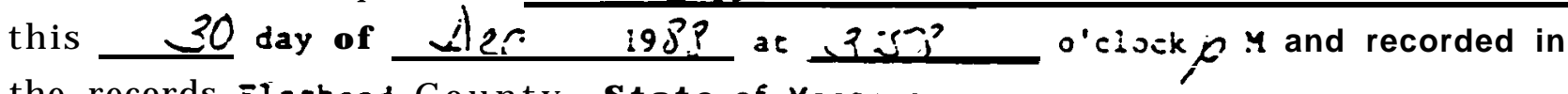
the records Elachead County. State of Moncana.

Fee $\mathrm{N} / \mathrm{C}$ ?d.

RECEPTION ${ }^{\circ}$ NO.

$58.565 / 55800$

REILRN TO

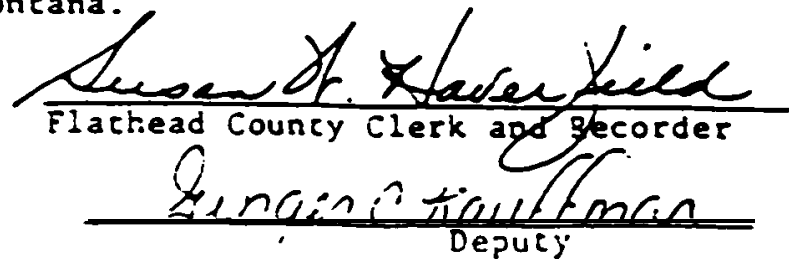

